\title{
7. CLAYEY NANNOFOSSIL OOZE TURBIDITES AND HEMIPELAGITES AT SITES 834 AND 835 (LAU BASIN, SOUTHWEST PACIFIC) ${ }^{1}$
}

\author{
R.G. Rothwell, ${ }^{2}$ P.P.E. Weaver, ${ }^{2}$ R.A. Hodkinson, ${ }^{3}$ C.E. Pratt, ${ }^{4}$ M.J. Styzen,${ }^{5}$ and N.C. Higgs ${ }^{2}$
}

\begin{abstract}
The western Lau Basin, between the Central and Eastern Lau Spreading Centers and the Lau Ridge, contains several small, elongate, fault-bounded, partially sediment-filled sub-basins. Sites 834 and 835 were drilled in the oldest part of the Lau Basin in two of these small extensional basins close to the Lau Ridge, formed on late Miocene to early Pliocene oceanic crust. Both sites show a similar sediment sequence that consists of clayey nannofossil oozes and mixed sediments interbedded with epiclastic vitric sands and silts. The vitric sands and silts are largely restricted to the deeper part of the sediment column (early Pliocene-late Pliocene), and the upper part of the sediment column at both sites consists of a distinctive sequence of brown clayey nannofossil ooze, stained by iron and manganese oxyhydroxides (late Pliocene-Holocene). However, the clayey nannofossil ooze sequence at Site 835 is anomalously thick and contains several medium- to very thick beds of matrix-supported, mud-clast conglomerate (interpreted as muddy debris-flow deposits), together with large amounts of redeposited clayey nannofossil ooze and coherent rafted blocks of older hemipelagic material.

Redeposited clayey nannofossil oozes can be distinguished from hemipelagic nannofossil oozes using several sedimentologi$\mathrm{cal}$ criteria. These include variation in color hue and chroma, presence or absence of bioturbation, presence or absence of scattered foraminifers, grain-size characteristics, variability in calcium carbonate content, presence or absence of pumice clasts, and micropaleontology. Clayey nannofossil ooze turbidites and hemipelagites are also geochemically distinct, with the turbidites being commonly enriched in $\mathrm{Mn}, \mathrm{Ni}, \mathrm{Pb}, \mathrm{Zn}, \mathrm{Cr}$, and $\mathrm{P}$.

The sediment sequence at Site 835 is dominated by allochthonous sediments, either muddy debris-flow deposits, coherent rafted blocks, or thick clayey nannofossil ooze turbidites. Since $2.9 \mathrm{Ma}$, only $25 \%$ of the $133 \mathrm{~m}$ of sediments deposited represents hemipelagic deposition, with an average sedimentation rate of $1.5 \mathrm{~cm} / \mathrm{k} \cdot \mathrm{y}^{-1}$. Allochthonous sediments were the main sediment type deposited during the Brunhes geomagnetic Epoch and make up $80 \%$ of the thickness of sediment deposited during this period. Short intervals of mainly hemipelagic deposition occurred from 0.4 to $0.9 \mathrm{Ma}, 1.0$ to $1.4 \mathrm{Ma}$, and 1.7 to $2.1 \mathrm{Ma}$. However, allochthonous sediments were again the dominant sediment type deposited between 2.1 and $2.5 \mathrm{Ma}$, with a large slide complex emplaced around $2.5 \mathrm{Ma}$. We conclude that the adjacent high ground, surrounding the basin in which Site 835 was drilled, was affected by marked instability throughout the late Pliocene and Pleistocene. In contrast, sedimentation at Site 834 during this period has been dominated by hemipelagic deposition, with redeposited sediments making up slightly less than $17 \%$ of the total thickness of sediment deposited since $2.3 \mathrm{Ma}$. However, there was a marked increase in frequency and magnitude of redeposited sediments at around $0.2 \mathrm{Ma}$ at Site 834, which broadly corresponds to the onset of a major episode of turbidite and debris-flow emplacement beginning about $0.4 \mathrm{Ma}$ at Site 835 . This episode of instability at both sites may be the effect of the approach and passing of the Central Lau propagator at the latitude of Sites 834 and 835 at about $0.5 \mathrm{Ma}$.
\end{abstract}

\section{INTRODUCTION}

The western Lau Basin, between the Central and Eastern Lau Spreading Centers and the Lau Ridge, contains several small, narrow, elongate, generally north-trending, fault-bounded, partially sedimentfilled sub-basins. These sub-basins range up to $600 \mathrm{~km}^{2}$ in area and are separated by subparallel, narrow, partially buried basement ridges that rise a few hundred meters above the basin floors, which lie at water depths ranging from 2500 to more than $2900 \mathrm{~m}$. Sites 834 and 835 were drilled in the oldest part of the Lau Basin in two sub-basins near the Lau Ridge (Figs. 1-2). Although the main drilling objectives for both sites were to sample the igneous basement rocks and to determine the age of the beginning of opening of the basin, an important objective was to obtain sedimentary, paleontologic, and paleomagnetic records from the basin fill.

Site 834 was drilled in a small sub-basin about $100 \mathrm{~km}$ east of the Lau Ridge and $150 \mathrm{~km}$ west of the propagating ridge that forms the Central Lau Spreading Center (Fig. 1). The sub-basin is about $8 \mathrm{~km}$

\footnotetext{
'Hawkins, J., Parson, L., Allan, J., et al., 1994. Proc. ODP, Sci. Results, 135: College Station, TX (Ocean Drilling Program).

${ }^{2}$ Institute of Oceanographic Sciences, Brook Road, Wormley, Godalming, Surrey, GU8 5 UB, United Kingdom.

${ }^{3}$ Department of Geology, Imperial College, Prince Consort Road, London, SW7 2BP, United Kingdom.

${ }^{4}$ Mineral Resources Department, Private Mail Bag. Suva, Fiji.

${ }^{5}$ Shell Offshore Inc., P.O. Box 61933, New Orleans, LA 70161, U.S.A.
}

wide at the latitude of Site 834 , but widens to about $14 \mathrm{~km}$ toward the south before narrowing toward its southern end. The northern limit of the basin is imprecisely known, but the longitudinal axis of the basin is at least $25 \mathrm{~km}$ and the basin has an area of approximately $500 \mathrm{~km}^{2}$. The basin (Fig. 2) is surrounded by relatively gentle slopes that rise above the basin floor by $1100 \mathrm{~m}$ in the east and $1600 \mathrm{~m}$ in the west. Gradients of the slopes that immediately flank the basin to the east and west are on the order of $3^{\circ}$. Single-channel seismic reflection data (Shipboard Scientific Party, 1992a) indicate that the sediment fill within the basin is about $0.17 \mathrm{~s}$ two-way traveltime. Drilling at Site 834 encountered basalt at a depth of $112.5 \mathrm{mbsf}$.

Site 835 was drilled in a fault-bounded graben, about $50 \mathrm{~km}$ directly to the east of Site 834 . This sub-basin is more than $2900 \mathrm{~m}$ deep and lies between two north-trending ridges to the east and west that rise to depths of 1800 and $1500 \mathrm{~m}$, respectively (Fig. 2). These ridges join to the south of the basin to form a broad bathymetric high. Parts of the basin near the drill site exceed a water depth of $2900 \mathrm{~m}$ and the basin floor gradually deepens toward the north, where it reaches depths in excess of $3000 \mathrm{~m}$. The scarps surrounding the basin rise above the basin floor by $1400 \mathrm{~m}$ to the west and by $1100 \mathrm{~m}$ to the east. Gradients on the slopes surrounding the basin are very steep, on the order of $10^{\circ}$ to the west, $4^{\circ}$ to $9^{\circ}$ to the south, and $10^{\circ}$ to $30^{\circ}$ to the east. The limits of the sub-basin are imprecisely known, but the basin is at least $9 \mathrm{~km}$ wide at the latitude of Site 835 and its longitudinal axis is at least $20 \mathrm{~km}$. The basin has an estimated area of approximately $160 \mathrm{~km}^{2}$. Single-channel seismic reflection data (Ship- 


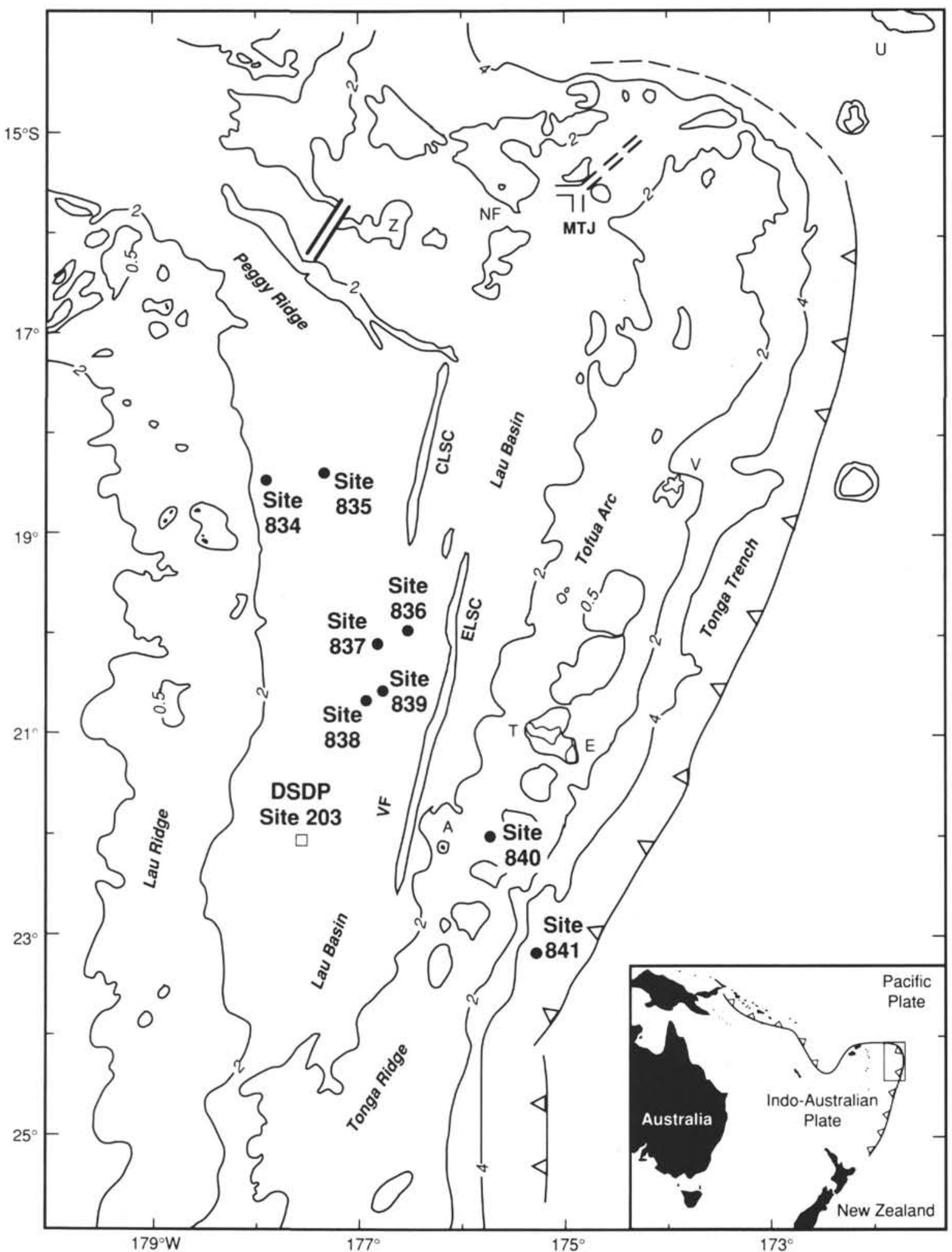

Figure 1. Map showing location of Ocean Drilling Program sites drilled in the Lau Basin, western Pacific, during Leg 135. Also shown are the main geologic features of the Tonga Trench and Lau Basin system. Islands shown are Ata (A), Tongatapu (T), 'Eau (E), Vavau (V) and Niua Fo'ou (NF). Locations of the Central Lau (CLSC) and East Lau Spreading Centers (ELSC), Zephyr Shoal (Z), Valu Fa Ridge (VF), and Mangatolu Triple Junction (MTJ) are also shown. Bathymetry in kilometers. 

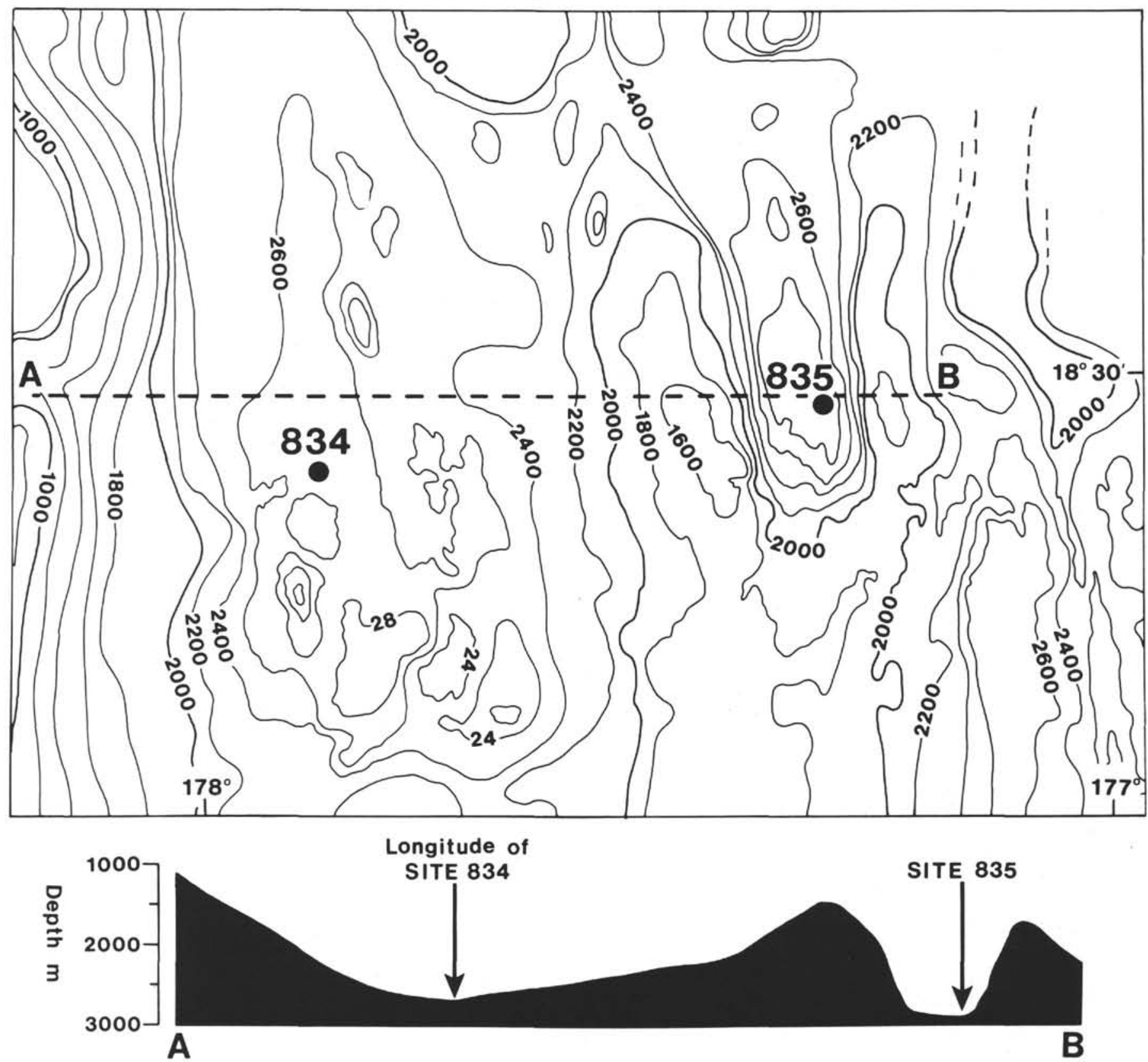

Figure 2. Local bathymetry around the two sub-basins containing Sites 834 and 835 . Contour interval $=200 \mathrm{~m}$. Bathymetric profile along Line A-B shown below (vertical exaggeration of $\mathrm{A}-\mathrm{B}$ profile $=8 \times$ ).

board Scientific Party, 1992b) indicate that the sediment fill is about $0.16 \mathrm{~s}$ two-way traveltime. Drilling at Site 835 encountered basalt at $155.1 \mathrm{mbsf}$.

Thus, both Sites 834 and 835 are located in adjacent extensional basins that formed on late Miocene to early Pliocene (3.5-6 Ma) oceanic crust. Site 834 is proximal to the Lau Ridge remnant arc, which was volcanically active from the ?Eocene to late Pliocene, after which erosion, subsidence, and the growth of coral reefs occurred (Gill, 1976; Woodhall, 1985). Site 835 is located on younger oceanic crust, is more distal to the Lau Ridge and more proximal to an active spreading center. However, the geometries of the basins are different, with the basin in which Site 834 was drilled being surrounded by relatively gentle slopes of $3^{\circ}$ to $4^{\circ}$, whereas those surrounding the Site 835 basin are extremely steep with gradients of $4^{\circ}$ to $30^{\circ}$ (Fig. 2).

\section{SEDIMENT SEQUENCE}

A continuous sediment sequence overlying basalts was cored at Sites 834 and 835 . Both sites show a similar sequence that consists of clayey nannofossil oozes and mixed sediments interbedded with epiclastic vitric sands and silts (Fig. 3). The vitric sands and silts are largely restricted to the deeper part of the sediment column and generally show an increase in thickness and frequency downhole (Shipboard Scientific Party, 1992a).

The upper part of the sediment column at both sites consists of a distinctive sequence of brown, iron and manganese oxyhydroxidestained, clayey nannofossil ooze. This sequence forms a distinct lithostratigraphic unit, termed Lithologic Unit I at both sites, and is $130 \mathrm{~m}$ thick at Site 835 , compared with a thickness of only $42 \mathrm{~m}$ at 
SITE 834

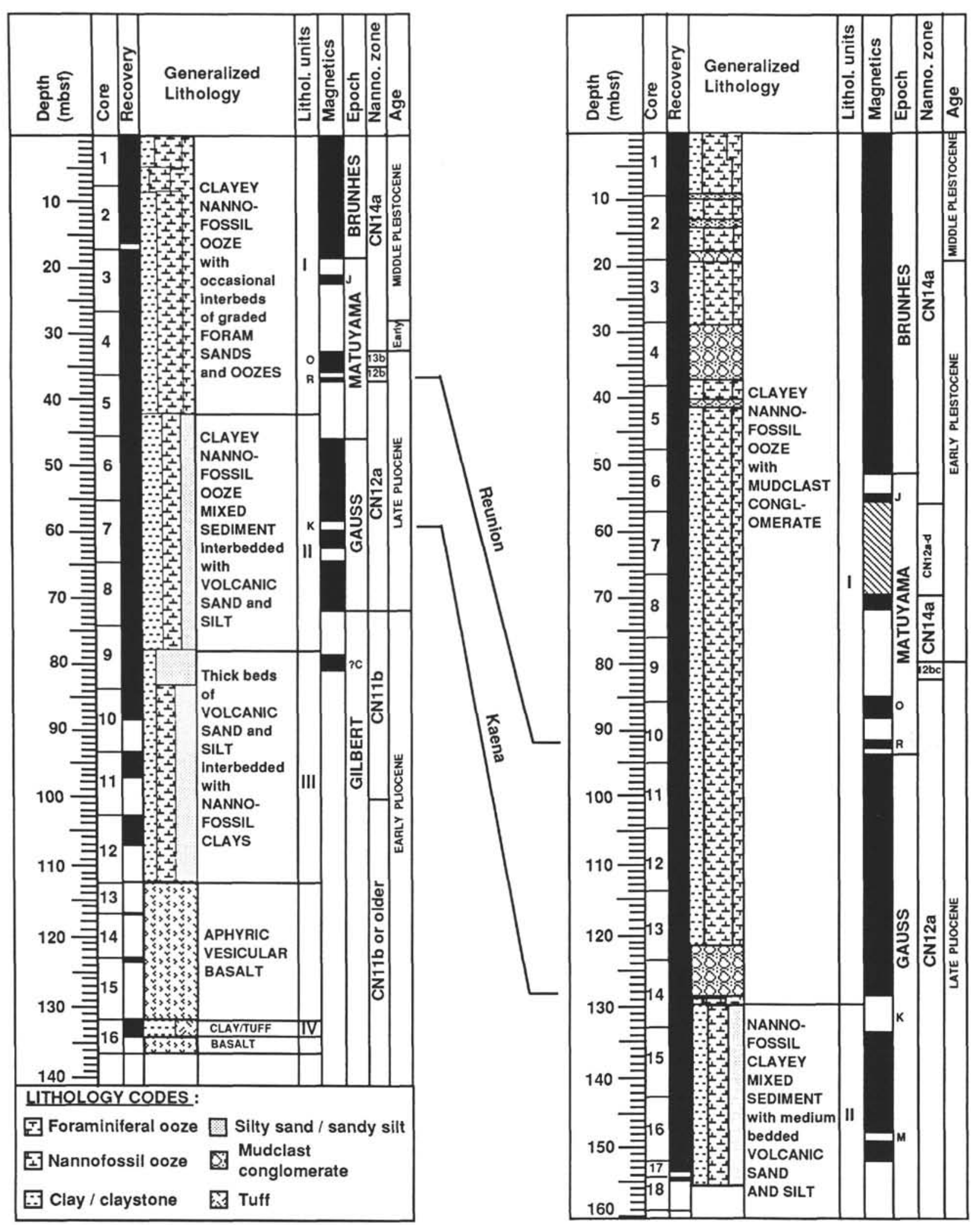

Figure 3. Downhole logs of the sediment sequence recovered at Sites 834 and 835 , showing generalized lithology determined through shipboard logging with shipboard paleomagnetic and biostratigraphic logs alongside. Note the anomalously thick clayey nannofossil ooze sequence in Lithologic Unit I at Site 835, as compared with the sequence found in Lithologic Unit I at Site 834. 
Site 834 (Fig. 3). Epiclastic vitric sands and silts are not present within Unit I, although it does contain several thin megascopic and disrupted ash layers that represent discrete air-fall pyroclastic events.

Lithologic Unit I at Site 835 contains several medium to very thick beds of matrix-supported, mud-clast conglomerate. These are interpreted as muddy debris-flow deposits. The total thickness of the mud-clast conglomerates is at least $20 \mathrm{~m}$. Such beds are not present at Site 834. Shipboard micropaleontologic data have also identified an additional redeposited block, $12.4 \mathrm{~m}$ thick, within the lower Pleistocene sediments of Unit I at Site 835 (Shipboard Scientific Party, 1992b). This interval contains a few thin layers of mud-clast conglomerate, but consists mainly of structureless mud that closely resembles the background hemipelagic deposits.

Paleomagnetic and biostratigraphic data suggest that, at Site 834, Unit I was deposited during the last 2.3 m.y. (Shipboard Scientific Party, 1992a). During this time, $42 \mathrm{~m}$ of sediments were deposited, of which about $7 \mathrm{~m}$ are redeposited nannofossil oozes and foraminiferal sands (calcareous turbidites). These contain many shallow-waterderived benthic foraminifers (e.g., Calcarina spengleri, Sorites marginalis) as well as Halimeda and abundant pteropod fragments (Shipboard Scientific Party, 1992a), suggesting that some of these turbidites are probably derived from carbonate reefs built up on the eroded Lau Ridge. If these deposits are regarded as being deposited by geologically instantaneous events, then the remaining $35 \mathrm{~m}$ of sediment was deposited over the last 2.3 m.y., giving an average sedimentation rate of 1.52 $\mathrm{cm} / \mathrm{k} \cdot \mathrm{y}^{-1}$. This is a relatively low sedimentation rate, consistent with wholly hemipelagic sedimentation. At Site 835, shipboard interpretation of the geomagnetic and biostratigraphic data suggests that deposition of Lithologic Unit I represents a time interval of perhaps 2.9 m.y. During this time, $130 \mathrm{~m}$ of sediment was deposited, of which $20 \mathrm{~m}$ consists of muddy debris-flow deposits and, a further $15 \mathrm{~m}$ represents a redeposited Pliocene block distinguished from micropaleontologic evidence. Assuming that these deposits resulted from geologically instantaneous events, the remaining $95 \mathrm{~m}$ of clayey nannofossil ooze reflects an average sedimentation rate of $3.2 \mathrm{~cm} / \mathrm{k} \cdot \mathrm{y} .{ }^{-1}$.

Assuming a constant rate of background hemipelagic deposition at both sites and considering that the lower sedimentation rate (1.5 $\mathrm{cm} / \mathrm{k} . \mathrm{y}^{-1}$ ) is closer to the average hemipelagic sedimentation rate, Lithologic Unit I at Site 835 must contain $80 \mathrm{~m}$ of additional redeposited material, as compared with the amount of material found at Site 834. The mud-clast conglomerate and the redeposited block account for only 30 to $35 \mathrm{~m}$ of this. We suspect that the remaining extra thickness may be caused by the presence of thick structureless, redeposited clayey nannofossil ooze that closely resembles the back- ground hemipelagic ooze deposits in both color and composition. A hemipelagic sedimentation rate of $1.52 \mathrm{~cm} / \mathrm{k} . \mathrm{y}^{-1}$ implies that perhaps only $44 \mathrm{~m}$ of the remaining $95 \mathrm{~m}$ of clayey nannofossil oozes in Unit I at Site 835 are true hemipelagic deposits. Therefore, $51 \mathrm{~m}$ of the remaining clayey nannofossil ooze at Site 835 is probably clayey nannofossil ooze turbidites rather than hemipelagites. However, we think that the clayey nannofossil ooze hemipelagites and turbidites can be distinguished by subtle sedimentologic criteria (Table 1).

\section{METHODS}

Irregularly spaced samples were taken from selected intervals of the sediment sequence at Sites 834 and 835 to substantiate the division of the sequence into genetic units, made primarily on sedimentologic criteria (Table 1). The sampling interval was variable and depended primarily on the thickness of the individual beds but was generally less that $70 \mathrm{~cm}$, and often substantially less. Individual samples were analyzed to determine their $\mathrm{CaCO}_{3}$ and organic carbon content and their grain-size characteristics, and used for major, minor, and trace element analyses. In addition, smear slides were made at regular intervals (generally $<1 \mathrm{~m}$ apart) throughout the sequence. These were examined using microscopy to identify the calcareous nannofossils making up the sediment. The resulting micropaleontologic data allowed us to determine whether the sediments were the result of hemipelagic accumulation or had been redeposited as turbidites or rafted blocks.

Samples for geochemical analysis were oven-dried at $110^{\circ} \mathrm{C}$ and hand-ground in agate. Calcium carbonate was determined via coulometric detection of the carbon dioxide evolved during acid attack of 25 -mg samples. Accuracy was monitored using in-house standards. Precision measured by replicate analyses was better than $1 \%$ relative. Total carbon was determined via coulometric detection of the carbon dioxide evolved on combustion of samples in $\mathrm{O}_{2}$ at $900^{\circ} \mathrm{C}$. Organic carbon was then determined by difference.

Major, minor, and trace element analyses were performed by inductively coupled plasma atomic emission spectroscopy (ICP-AES) after digestion of samples with a combination of hydrofluoric, perchloric and nitric acids (Totland et al., 1992). Accuracy was checked using standard reference materials and was monitored using in house standards. Precision was better than $5 \%$ for all elements.

Grain-size characteristics were determined using a Sedigraph 5000 ET particle-size analyzer. About $6 \mathrm{~cm}^{3}$ of sample was used for each analysis. Each sediment sample was prepared by adding $10 \mathrm{~cm}^{3}$ of distilled water containing $0.5 \%$ sodium hexametaphosphate, used as a

Table 1. Characteristics of clayey nannofossil ooze turbidites and hemipelagites at Site 835, Lau Basin.

\begin{tabular}{|c|c|c|}
\hline & Hemipelagites & Turbidites \\
\hline Color & $\begin{array}{l}\text { Reddish brown to orange-brown colors which show } \\
\text { subtle variation in hue and chroma over short } \\
\text { segments of core }\end{array}$ & $\begin{array}{l}\text { Reddish brown to orange-brown colors which are of } \\
\text { consistent hue and chroma, sometimes over long } \\
\text { intervals }\end{array}$ \\
\hline Bioturbation & Slight mottling due to bioturbation sometimes occurs. & $\begin{array}{l}\text { Sediment appears to be homogeneous; bioturbation } \\
\text { occurs only near the tops of units. }\end{array}$ \\
\hline Foraminifer distribution & $\begin{array}{l}\text { Occur scattered throughout sediment. Sediment } \\
\text { appears speckled under a hand lens. }\end{array}$ & $\begin{array}{l}\text { Large foraminifers rare or absent, except near base of } \\
\text { units. Sediment appears featureless under hand lens. }\end{array}$ \\
\hline Texture & Cut core surface frequently slightly pitted & Cut core surface usually smooth \\
\hline Grain-size characteristics & $\begin{array}{l}\text { Grain-size spectra variable over short segments of } \\
\text { core. Contains variable sand/coarse silt modes. } \\
\text { Variable sorting values. }\end{array}$ & $\begin{array}{l}\text { Spectra very consistent over depositional intervals. } \\
\text { Characterized by persistent, restricted coccolith } \\
\text { modes, sand/coarse silt modes absent. Restricted } \\
\text { sorting values. }\end{array}$ \\
\hline $\mathrm{CaCO}_{3} / \mathrm{C}_{\text {org }}$ & Variable over short core segments & $\begin{array}{l}\text { Consistent over depositional intervals; can be several } \\
\text { tens of meters in thickness. }\end{array}$ \\
\hline Micropaleontology & Discoasters absent from Pleistocene hemipelagites & May contain a variable proportion of discoasters \\
\hline Dropstones & Weathered pumice clasts common & Absent \\
\hline Geochemical analysis & Chemistry variable & $\begin{array}{l}\text { Geochemical profiles show consistent chemistry over } \\
\text { depositional intervals. Frequently clear differences } \\
\text { in element concentrations to enclosing } \\
\text { hemipelagites. }\end{array}$ \\
\hline
\end{tabular}


antiflocculent. Samples were disaggregated to form a viscous slurry by rotating in a rotating spindle at $25 \mathrm{rpm}$ for $24 \mathrm{hr}$. Samples were then diluted further and analyzed using the Sedigraph 5000 ET particle sizer. Three principle grain-size parameters were determined from the resulting granulometric curves: percentage of silt, silt/clay ratio, and median grain size (Md50) measured in microns $(\mu \mathrm{m})$. The percentage of material within each $0.25-\phi$ size class was calculated and then plotted as frequency distribution curves with arithmetic ordinates (grain-size spectra) and stacked one on top of one another to identify persistent modes and modal variation throughout the turbidite.

Shipboard compressional velocity logs measured by the $P$-wave logger, and downhole resistivity, standard gamma-ray, bulk density, and Formation MicroScanner (FMS) logs were examined to substantiate the lithologic interpretations. Estimation of the ages of depositional events were made primarily from calculation of the average hemipelagic sedimentation rate, constrained by shipboard paleomagnetic dating.

\section{DIFFICULTIES IN DISTINGUISHING BETWEEN TURBIDITES AND HEMIPELAGIC MUDS}

Bouma (1962) proposed a now universally accepted structural scheme for turbidites in which all fine material was classified as $e$ division mud. Kuenen (1964) divided the $e$ division into $e_{t}$ (turbiditic mud) and $e_{p}$ (pelagic or hemipelagic mud) to distinguish between mud deposited by the turbidity current and the overlying mud deposited by pelagic and/or hemipelagic processes. Van der Lingen (1969) and Hesse (1975) used the letter $e$ for turbiditic mud and $f$ for pelagic/ hemipelagic mud. Piper (1978) subdivided turbiditic mud $(e)$ into three structural divisions $-e_{1}$ (laminated mud), $e_{2}$ (graded mud), and $e_{3}$ (ungraded mud) - and retained the $f$ notation for overlying hemipelagic or pelagic sediment. The boundary between turbiditic mud $(e)$ and the overlying hemipelagic or pelagic mud $(f)$ is typically bioturbated or gradational.

If turbidites are markedly different in color to the enclosing hemipelagic or pelagic sediments and if the hemipelagic or pelagic sediments are moderately to heavily bioturbated, one may distinguish relatively easily between the turbiditic and hemipelagic or pelagic muds (cf. Weaver and Kuijpers, 1983; Weaver and Rothwell, 1987; Rothwell et al., 1992). However, in instances where the turbidites are similar in color and bioturbation of the sediments is low, it can be difficult to determine the boundaries between $e$ and $f$ division muds. Many authors (e.g., Kelts and Arthur, 1981; Wetzel, 1986; Shipboard Scientific Party, 1987; Pilkey, 1987; Brunner and Normark, 1985; Brunner and Ledbetter, 1987; and many others) discussed or noted difficulty in identifying turbidite muds and/or in establishing the true thicknesses of turbidites (and, hence, the proportion that turbidite muds make up of particular sediment columns). Biogenic turbidites can be particularly difficult to distinguish, as their composition, color, and sometimes the biostratigraphic age of the contained microfossils may be similar to the enclosing hemipelagic sediments. This is especially true in regions where the organic carbon content of the sediment is low (such as the Lau Basin) and, hence, there is little bioturbation of the hemipelagic sediments to distinguish them from turbidite muds. The pervasive staining of the Lau Basin sediments by hydrothermally derived iron and manganese oxyhydroxides effectively masks any color differences between the hemipelagic and redeposited beds.

Kelts and Arthur (1981) reported that thick turbidite muds have not been widely recognized in sediment sequences from Deep Sea Drilling Project (DSDP) sites. This is undoubtedly because they are often difficult to discern in disturbed intervals and because many sequences of hemipelagic mud are monotonous and often of minor interest to shipboard scientists. Turbidite muds may often remain unrecognized. Indeed, Klein (1985), in a synthesis of western Pacific backarc basins, reported that silty basinal turbidites make up less than $6 \%$ of the total sediment volume, but that hemipelagic clays were the second most widespread sediment type and that most of the clays were structureless. It seems probable that many of these structureless "hemipelagic" clays may, in fact, be unrecognized turbidite muds.

\section{SEDIMENTOLOGIC CRITERIA USED TO DISTINGUISH CLAYEY NANNOFOSSIL OOZE TURBIDITES AND HEMIPELAGITES}

The sediments of Lithologic Unit I in Hole 835 consist of clayey nannofossil oozes, foraminiferal sands and sandy oozes, thick mudclast conglomerates, and thin pyroclastic ash beds (Shipboard Scientific Party, 1992b). Petrographically, the clayey nannofossil oozes consist of about $35 \%$ clay-sized material, with the rest of the sediment being composed primarily of calcareous nannofossils (55-65 vol\%) and a much smaller percentage of planktonic foraminifers (3-10 vol\%). The ratio of clay-grade material to calcareous nannofossils remains fairly constant throughout Lithologic Unit I (Shipboard Scientific Party, 1992b).

It is clear from consideration of sedimentation rates that much of the clayey nannofossil ooze in Lithologic Unit I at Site 835 is redeposited. Despite similarity to the enclosing hemipelagic clayey nannofossil ooze, the redeposited clayey nannofossil ooze may be distinguished on the following criteria.

\section{VISUAL CHARACTERISTICS}

\section{Bed Organization}

Turbiditic muds frequently overlie foraminiferal sands and sandy oozes and these frequently have sharp, planar, or sometimes scoured bases. The upper boundaries of turbiditic muds are usually gradational, with overlying hemipelagites. Turbidites frequently overlie intervals of mud-clast conglomerate, although sequences are often complicated by the common occurrence of rafted hemipelagite blocks above and between beds of mud-clast conglomerate (see below).

\section{Color}

The clayey nannofossil oozes throughout Unit I are pervasively stained moderate yellowish brown to dark yellowish brown throughout by hydrothermally derived iron and manganese oxyhydroxides. Both the turbiditic and hemipelagic clayey nannofossil oozes are thus stained a similar color within the color hue 10YR and 5YR (Munsell Color Chart, Goddard et al., 1979). However, hemipelagic sediments within the sequence typically show slight variations in chroma and color value. Typically colors shown by the hemipelagites are moderate yellowish browns (10YR 5/2 to 10YR 5/4), dark yellowish browns (10YR $4 / 2$ to 10YR 4/4), and grayish to moderate browns (5YR $3 / 2$ to 5 YR 3/4). Variations in shade often occur over short intervals of hemipelagite, and color changes are often diffuse and irregular. Turbiditic sediments are much more consistent in chroma and color value. The turbidites are therefore more restricted in color than the hemipelagites, typically being uniform dark yellowish brown (10YR $4 / 2$ ) or uniform moderate yellowish brown (10YR 5/2 and 10YR 5/4). Where turbidites are several meters thick, they are typically of uniform hue, chroma and color value over their entire thickness. This uniformity in color may be for up to $20 \mathrm{~m}$.

\section{Bioturbation/Color Mottling}

Hemipelagic intervals may show slight mottling caused by bioturbation although in Leg 135 sediments the intensity of bioturbation is usually light. However, some intervals interpreted as hemipelagic from other criteria may show little or no bioturbation. However, turbiditic muds are homogeneous, although such intervals may show slight bioturbation near their upper boundaries. Thick turbidite beds correspond to long homogeneous intervals (frequently several meters thick). The X-radiographs of turbiditic intervals clearly show their lack of bioturbation compared to the hemipelagic intervals (Fig. 4). 
A

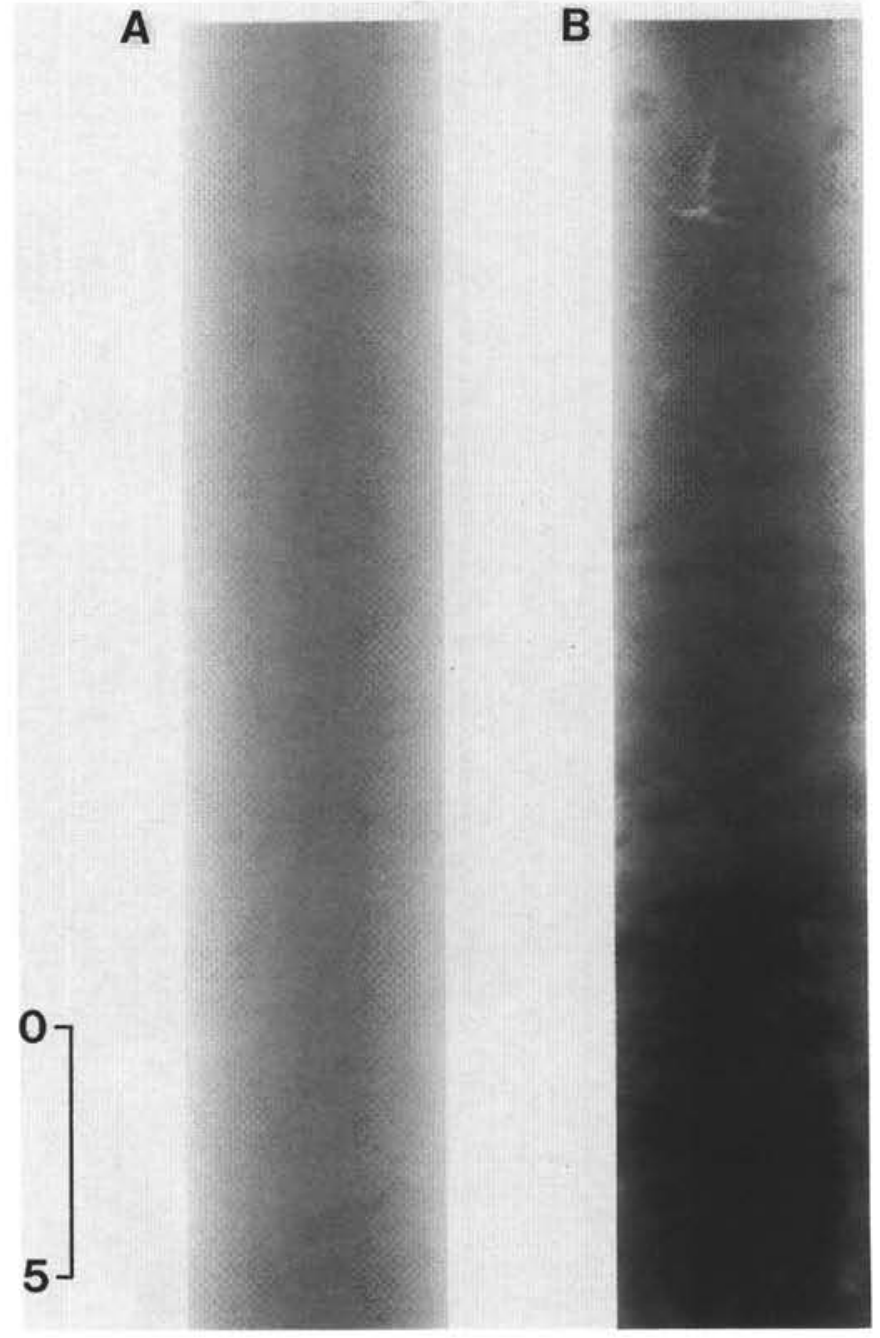

Figure 4. X-radiographs of (A) clayey nannofossil ooze turbidite mud (Te) (Interval 135-835A-1H-4, 20-45 cm) and (B) clayey nannofossil ooze hemipelagic mud (Interval 135-835A-5H-3, 3-27 cm). Note the structureless appearance of the turbiditic mud (A) compared to the bioturbated hemipelagic mud (B). Scale bar $=5 \mathrm{~cm}$.

\section{Distribution of Foraminifers}

Hemipelagic intervals typically contain abundant scattered foraminifers that give the sediment a "speckled" appearance when examined under a hand lens. These foraminifers show a wide range of grain size, with large, sand-sized foraminifers being common. In the turbiditic intervals, large foraminifers are rare or absent, except near the bases, which are frequently marked by foraminiferal sands. Turbiditic sediments, therefore, appear relatively featureless when examined under a hand lens. Sometimes foraminifers do occur within the turbidite muds, but generally they are uncommon compared with their occurrence in the hemipelagic intervals and they are restricted in size (typically being in the silt grain-size range and consisting of juveniles and broken test fragments of mature forms).

The cut core surface is frequently pitted through hemipelagic intervals because of large sand-sized foraminifers catching on the cheese-wire as it passed through the core during splitting. The cut core surface through turbidite muds is usually smooth resulting from the absence of large foraminifers in these intervals (Fig. 5).

\section{Presence or Absence of Pumice Clasts}

Rounded and often weathered pumice clasts of variable size are scattered throughout the hemipelagic intervals. These are totally absent from the turbidite muds, although they may occur within the coarse turbidite bases. Some of the pumice clasts in the hemipelagites are surrounded by thin light-colored haloes from in-situ weathering of the pumice.

\section{GRAIN-SIZE CHARACTERISTICS}

Grain-size analysis, using a Sedigraph 5000 ET particle-size analyzer, shows that the hemipelagic nannofossil oozes have a variable sand and silt content over short intervals. The silt content of the hemipelagic intervals typically ranges from $24 \%$ to $55 \%$, with a sand content up to $4 \%$. Turbiditic nannofossil oozes ( $\mathrm{Te}$ division mud) contain $40 \%-45 \%$ silt-grade material, and this percentage is fairly constant throughout the Te mud interval (Fig. 6). Sand-sized material is less than $1 \%$ or is absent. However, sand does appear to increase in percentage toward the bases of the turbidites, which are frequently marked by graded foraminiferal sands. The content of silt and sand in both the hemipelagic and turbidite units mainly reflects the presence and distribution of the foraminifers. Sand- and silt-sized foraminifers are abundant in the hemipelagic sediments, but in the Te turbidite muds, sand-sized foraminifers are rare or absent, although juvenile foraminifers and broken test fragments of restricted size range (medium to fine silt) and similarly sized silt-grade material occur. The proportion of this material within an interval of turbidite mud ( $T e$ ) remains fairly constant, showing that turbidite muds are ungraded and largely compose the $e_{3}$ structural division of Piper (1978). Within these intervals, which can be several meters thick, no detectable systematic gradation in grain size can be seen (Fig. 6).

Median grain-size (Md50) and silt/clay ratio profiles through segments of core containing both hemipelagic and turbiditic clayey nannofossil oozes (Fig. 6) show that these parameters are variable (especially the silt/clay ratio) within the hemipelagic units, but are constant and consistent in the turbidite muds.

Stacked grain-size frequency distribution curves (grain-size spectra) for hemipelagic clayey nannofossil oozes (Fig. 7) are highly variable over short segments of core. In contrast, grain-size frequency distribution curves for turbiditic clayey nannofossil oozes are remarkably similar and consistent, often over long intervals. Thick $T e$ muds show similar grain-size spectra throughout the depositional intervals characterized by persistent, restricted coccolith modes (Fig. 7). Sand/ coarse silt modes, which are prominent in the hemipelagic units, are absent from the $T e$ muds, although persistent fine- and medium-grained silt modes are present throughout the Te mud units.

The hemipelagic intervals show variable sorting values (defined as the inclusive graphic standard deviation of Folk, 1974), whereas restricted sorting values are characteristic of the turbidite muds (Fig. 8 ). Sorting values increase in the coarser basal foraminiferal sands.

\section{CALCIUM CARBONATE AND ORGANIC CARBON CONTENT}

The calcium carbonate content of the clayey nannofossil oozes of Lithologic Unit I in Hole 835 generally ranges from $55 \%$ to $65 \%$, although hemipelagic intervals show much greater variability in $\mathrm{CaCO}_{3}$ content than turbiditic intervals. The $\mathrm{Te}$ turbidite muds usually show a constant $\mathrm{CaCO}_{3}$ content over their entire thickness, which can be several meters (Fig. 9). The organic carbon content of Lau Basin sediments is typically very low. Values for the clayey nannofossil oozes in Hole 835 range from $0.01 \%$ to $0.4 \% \mathrm{C}_{\text {org }}$, with very low values being more common than higher values (Fig. 9). Little detectable difference is seen between the organic carbon contents of the turbiditic and the hemipelagic oozes. 

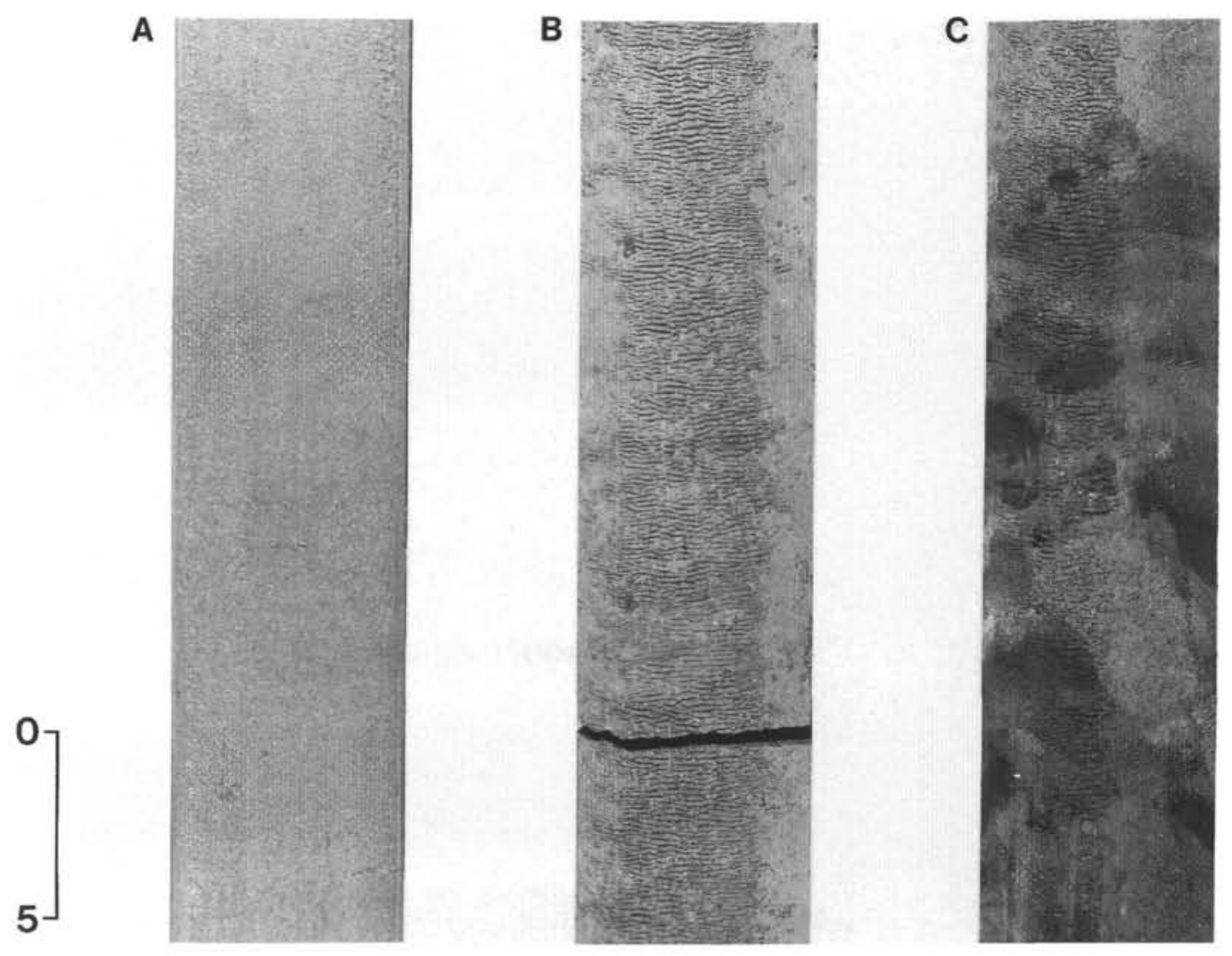

Figure 5. Photograph of cut core surfaces, showing the three main lithologies present in the upper Pliocene-Pleistocene sequence at Site 835. A. Clayey nannofossil ooze turbidite mud (Bouma Te division) (Interval 135-835A-1H-4, 50-74 cm). B. Clayey nannofossil ooze hemipelagic mud (Interval 135-835A-8H-6, 85-111 cm). C. Mud-clast conglomerate (debrite) (Interval 135-835A-13H-6,95-119 cm). Note the pitted cut core surface caused by scattered foraminifers in the hemipelagic mud (B), compared to the smooth surface of the turbiditic mud (A). Scale bar $=5 \mathrm{~cm}$.

\section{GEOCHEMICAL DIFFERENCES}

Analysis of major and minor elements by inductively coupled plasma atomic emission spectroscopy (ICP-AES) of sediment samples from the hemipelagic and turbiditic clayey nannofossil oozes show clear geochemical differences between the two sediment types. Turbidites are sometimes enriched in $\mathrm{Mn}, \mathrm{Ni}, \mathrm{Pb}, \mathrm{Zn}, \mathrm{Cr}$, and $\mathrm{P}$ compared to the enclosing hemipelagic intervals (Figs. 10-11 and Tables 2-3). The manganese in these sediments is of hydrothermal derivation, and $\mathrm{Mn}$ tends to co-precipitate $\mathrm{Zn}, \mathrm{Cu}, \mathrm{Ni}$, and $\mathrm{Pb}$ (Hodkinson and Cronan, this volume). Consequently the increased concentrations of these elements in the clayey nannofossil ooze turbidites reflect their increased Mn content. However, more distinctively, the vertical profiles of particular elements within a single turbidite bed are typically fairly straight, showing that element concentrations throughout single turbidites are fairly constant, even over several meters. In contrast, elemental concentrations in the hemipelagic nannofossil oozes tend to be variable, even on decimeter to centimeter scales (Figs. 10-11). Abrupt changes in vertical geochemical profiles through cores nearly always correlate with lithologic changes in the sediments, such as turbidite/hemipelagite boundaries.

\section{MICROFOSSIL CONTENT}

Turbiditic clayey nannofossil oozes present within the Pleistocene section frequently contain reworked late Pliocene taxa (Shipboard Scientific Party, 1992b). These beds may contain up to 5\% reworked discoasters. A number of apparently coherent hemipelagic intervals in the Pleistocene sequence were identified as probable rafted blocks by their Pliocene microflora. Turbidites often contain small amounts of sand-sized foraminifers ( $<1 \%)$, even within the $T e$ Bouma division mud. However, coarse-fraction studies show that these tend to be exclusively small juvenile forms or test fragments of mature forms. Large complete planktonic foraminifer tests are very rare in the clayey nannofossil ooze turbidite muds, although they are abundant in the basal foraminiferal sands underlying these and are very common in the hemipelagic clayey nannofossil oozes.

Great care must be exercised when interpreting sequences having reworked turbidites and rafted blocks. Site 835 provides a good example of how the pelagic signal can be extracted from the mass of conflicting age data using micropaleontology. Figure 12 shows the downhole nannofossil data irrespective of lithology. Discoasters are common in most samples, and last appearance datums (LADs) and first appearance datums (FADs) of all species are difficult to identify. When the lithologic interpretations are added, however, the definite pelagic intervals can be recognized and abstracted (Fig. 13). The progression of LADs and FADs is now revealed and anomalous samples can be identified for further lithologic examination. Samples from uncertain lithologies can be micropaleontologically analyzed to see if they fit the pelagic distribution pattern of species or the reworked pattern. This type of iteration leads eventually to a strong correspondence between lithologic and micropaleontologic criteria for distinguishing the pelagic sequence in the core. The biostratigraphic information from the pelagic intervals can then be plotted as an accumulation rate diagram, leaving out the reworked intervals (Tables 4-5 and Figs. 14-15). Providing that there has been no significant erosion of the underlying hemipelagites by turbidity currents, sedimentation rate curves should plot as fairly straight lines. 


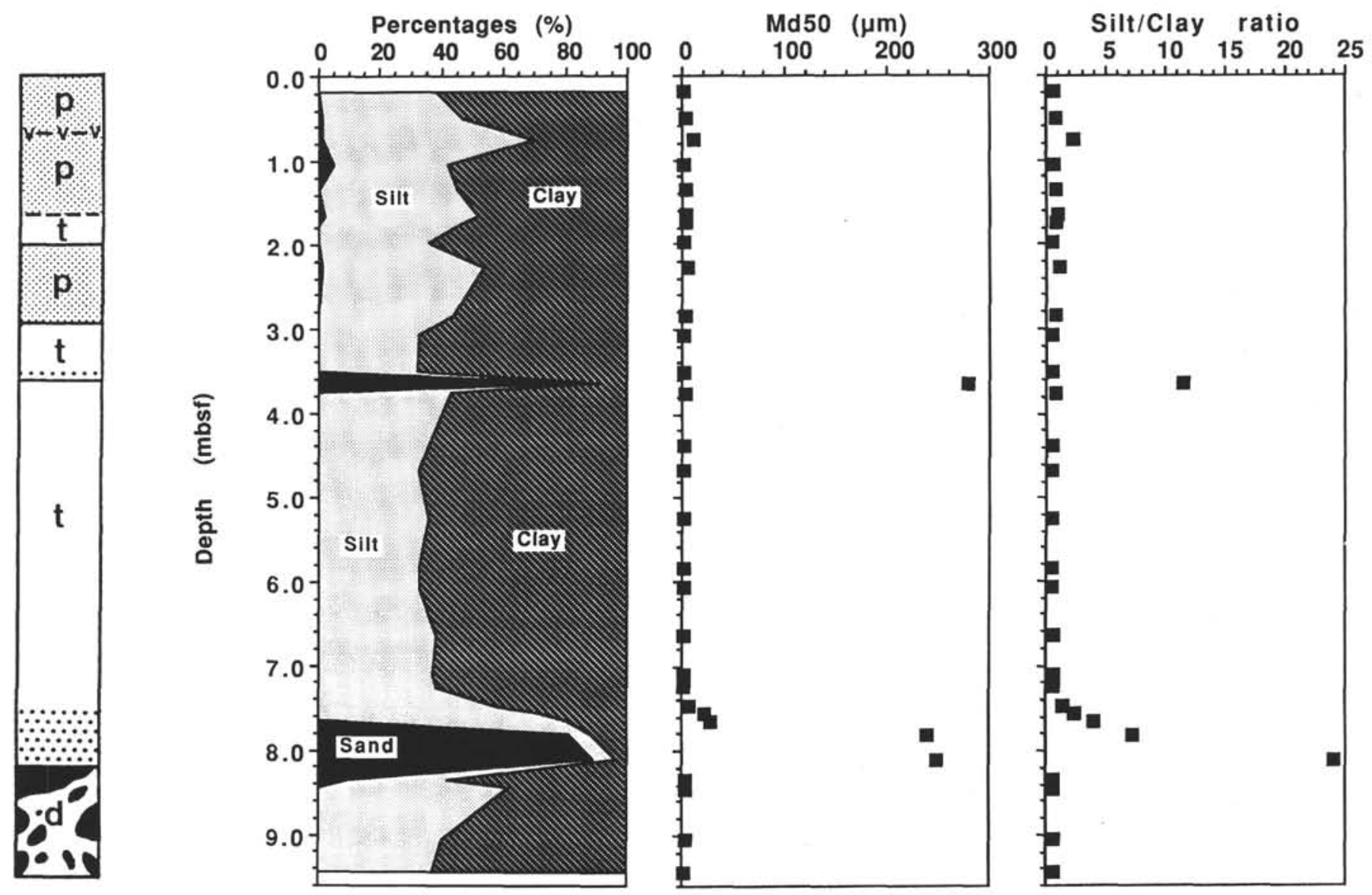

Figure 6. Graphic log through Core 135-835A-1H (0-9.5 mbsf), showing a sequence of clayey nannofossil ooze hemipelagites (p) and turbidites ( $t$ ), overlying a debrite (d) with downcore percentage of sand/silt/clay, Md50, and silt/clay ratio profiles alongside. A thin pyroclastic ash layer is indicated by " $\mathrm{v}$ " in the graphic log.

\section{PHYSICAL PROPERTY DIFFERENCES}

Shipboard measurements of grain density, wet-bulk density, water content, porosity, and void ratio showed little change throughout Lithologic Unit I at Site 835. The first significant change in these properties appears to correlate with the first occurrence of volcaniclastic turbidites at $135 \mathrm{mbsf}$, where increases in water content, porosity, and void ratio were seen (Shipboard Scientific Party, 1992b). However, compressional velocity, measured by the $P$-wave logger (see Fig. 22), shows great variability throughout, with numerous high-velocity peaks that correlate with the basal turbidite foraminiferal sand layers. However, an interval of generally decreased velocities between 50 and 65 mbsf shows no obvious correlation with lithostratigraphy. Several distinct geotechnical units were defined by shipboard measurements of undrained shear strength, which broadly correlate with lithostratigraphy (see discussion below).

\section{DEPOSITIONAL HISTORY AT SITES 834 AND 835 DURING THE LAST 3 M.Y.}

Identification of redeposited beds of clayey nannofossil ooze, using the above criteria, has allowed genetic logs to be constructed for Lithologic Unit I at both Sites 834 and 835 (Figs. 16-17). Subtraction of the redeposited units from the sediment sequence at both sites enables sedimentation rate curves to be drawn for the background hemipelagic deposition (see Figs. 14-15). As would be expected, providing no hiatuses occur, the resulting fairly straight lines show an average background hemipelagic sedimentation rate of $1.46 \mathrm{~cm} / \mathrm{k} . \mathrm{y}^{-1}$ for Site 834 and $1.44 \mathrm{~cm} / \mathrm{k} . \mathrm{y} .^{-1}$ for Site 835 . This is in reasonably close agreement with the $1.5 \mathrm{~cm} / \mathrm{k} . \mathrm{y} .^{-1}$ reported by Reich et al. (1990) for an average hemipelagic sedimentation rate in piston and gravity cores from the Lau Basin, and the average rate of 1.52 $\mathrm{cm} / \mathrm{k} . \mathrm{y}^{-1}$ estimated earlier.

\section{Site 834}

Redeposited sediments make up slightly less than $17 \%$ of the total thickness of sediment deposited in Lithologic Unit I at Site 834 (Fig. 16). This depositional interval covers a period extending back from the present to about 2.3 Ma. Allochthonous sediments within Lithologic Unit I consist entirely of generally thick to thinly bedded $(0.6-0.02 \mathrm{~m})$, redeposited clayey nannofossil oozes, often with thin basal foraminiferal sands. However, there has been a marked increase in frequency of turbidite emplacement since $200 \mathrm{ka}$. Two thick-bedded turbidites, having sandy bases each just over $1 \mathrm{~m}$ thick emplaced directly on top of one another, were emplaced about $200 \mathrm{ka}$ (in Sections $135-834 \mathrm{~A}-1 \mathrm{H}-4,20 \mathrm{~cm}$, to $-2 \mathrm{H}-1,95 \mathrm{~cm}, 4.70-8.55 \mathrm{mbsf})$ and a less thick, similar couplet of medium- to thick-bedded turbidites, having sandy bases, occurred at around $28 \mathrm{ka}$ (in Sections 135-834A-1H-1, $42 \mathrm{~cm}$, to $-1 \mathrm{H}-2,26 \mathrm{~cm}, 0.42-1.76 \mathrm{mbsf}$ ). Between these, a medium- to thick-bedded mud turbidite was emplaced at about $60 \mathrm{ka}$ (in Section 135-834A-1H-2, 71-111 cm, 2.21-2.61 mbsf) and a thin-bedded mud turbidite at $125 \mathrm{ka}$ (in Section $135-834 \mathrm{~A}-1 \mathrm{H}-$ 3, 56-69 cm, 3.56-3.69 mbsf). Between $200 \mathrm{ka}$ and $1.7 \mathrm{Ma}(8.55-$ $32.00 \mathrm{mbsf}$ ), turbidite frequency is seen to be one "event" (singly thinly bedded turbidite or a small group of thinly bedded turbidites) every 170 to 275 k.y. Between 1.7 and $2.3 \mathrm{Ma}$, sedimentation at Site 834 was almost exclusively hemipelagic. 

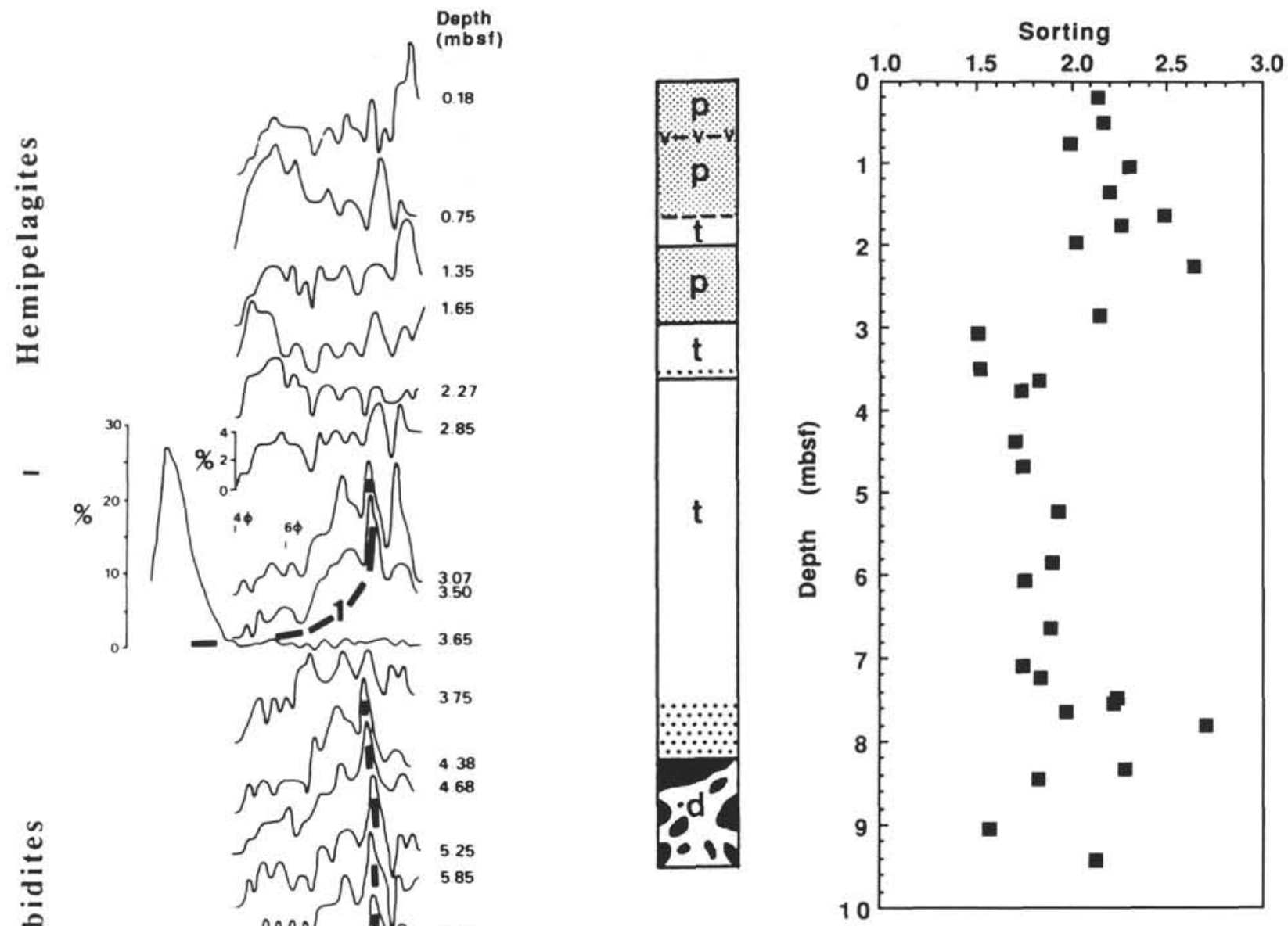

Figure 8. Sorting values (defined as the inclusive graphic standard deviation of Folk, 1974) through Core $135-835 \mathrm{~A}-1 \mathrm{H}(0-9.5 \mathrm{mbsf})$. Note their variability in the hemipelagic intervals $(0-3 \mathrm{mbsf})$ and the restricted sorting values characteristic of the turbidite muds ( $3-8 \mathrm{mbsf}$ ). Sorting values increase in the coarser basal foraminiferal sands. See Figure 6 caption for key to graphic log of core.

\section{Site 835}

Clearly, the sediment sequence represented by Lithologic Unit I at Site 835 is dominated by redeposited sediments, either coherent rafted blocks, muddy debris-flow deposits (represented by mud-clast conglomerates), or clayey nannofossil ooze turbidites (Fig. 17). During the last 3.0 m.y., redeposited sediments have made up about $75 \%$ of all sediments deposited, and several episodes of instability can be recognized.

The time interval from 0 to $0.5 \mathrm{Ma}$ was a period of marked instability at Site 835 . Around $185 \mathrm{ka}$, a major slide complex was emplaced that comprised a thick muddy debris flow directly overlain by a very thick $(7.75 \mathrm{~m})$, clayey nannofossil ooze turbidite with a basal massive, graded foraminiferal sand, $0.85 \mathrm{~m}$ thick (in Sections $135-835 \mathrm{~A}-3 \mathrm{H}-3,40 \mathrm{~cm}$, to $-4 \mathrm{H}-6,5 \mathrm{~cm}, 22.40-36.05 \mathrm{mbsf}$ ). This turbidite is directly overlain by a series of thinner clayey nannofossil ooze turbidites. Directly above these, a series of muddy debris flows carry coherent rafted blocks of Pliocene hemipelagic material, 0.4 to $1.85 \mathrm{~m}$ thick (in Sections $135-835 \mathrm{~A}-1 \mathrm{H}-6,98 \mathrm{~cm}$, to $-3 \mathrm{H}-1,140 \mathrm{~cm}$ [8.38-20.40 mbsf]). The whole slide complex is topped by thick to very thick-bedded (up to $4.5 \mathrm{~m}$ ) clayey nannofossil ooze turbidites. The redeposited sediments making up this complex measure $33 \mathrm{~m}$ in total thickness, and, as far as we can ascertain, no in-situ hemipelagic intervals are present within these deposits (i.e., from Sections 135$835 \mathrm{~A}-1 \mathrm{H}-3,0 \mathrm{~cm}$, to $-4 \mathrm{H}-6,5 \mathrm{~cm}$ [3.00-36.05 mbsf]). Consequently, it seems likely that these sediments were deposited in quick succes- 


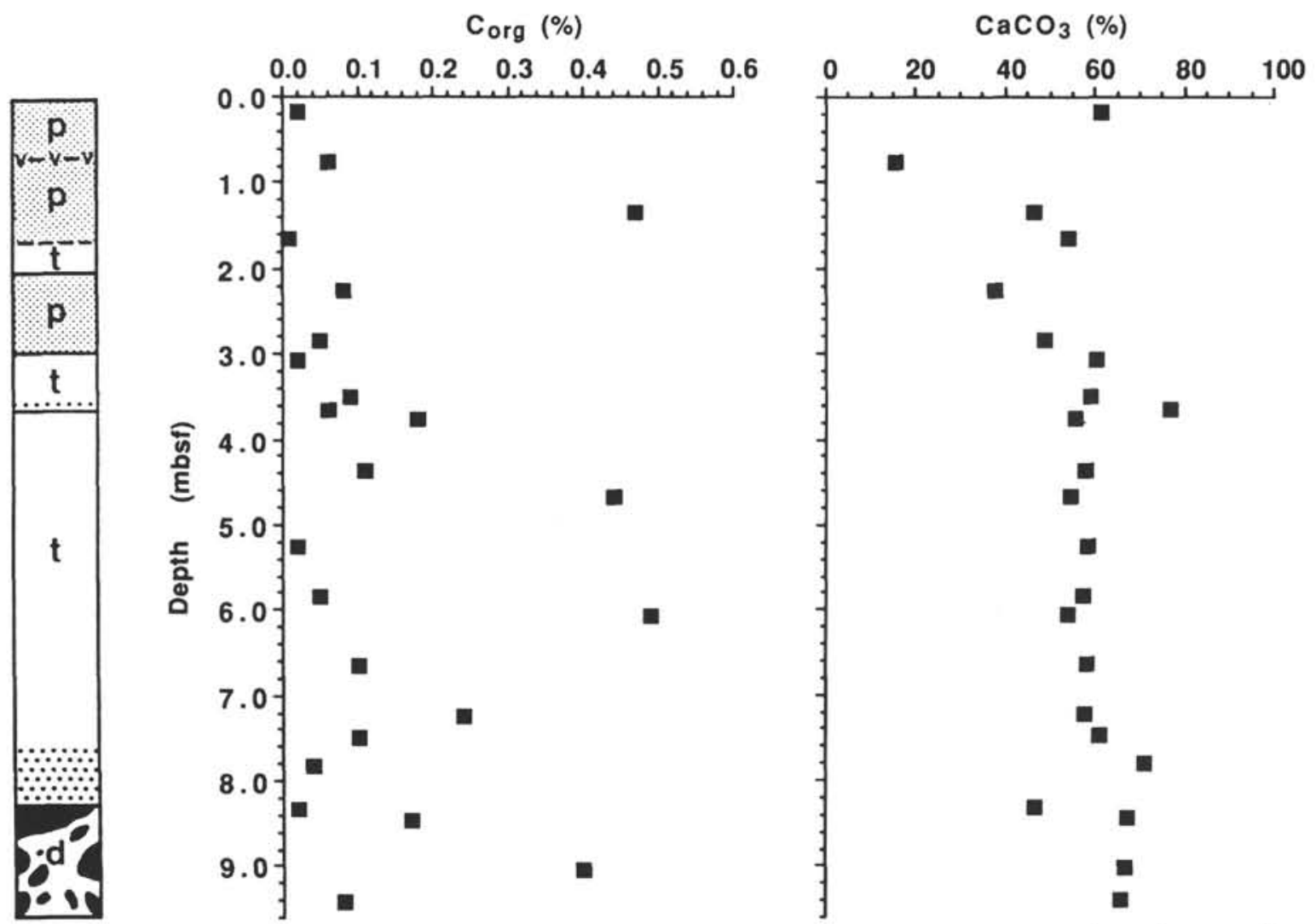

Figure 9. Downcore organic carbon and $\mathrm{CaCO}_{3}$ profiles through Core 135-835A-1H (0-9.5 mbsf). See Figure 6 caption for key to graphic $\log$ of core.

sion. However, the presence of thick turbidite mud (21-31 mbsf; Fig. 17), suggests that sufficient time (months, years) must have elapsed for the $T e$ division mud to settle and consolidate before the emplacement of the overlying debris flow and rafted blocks, which, if emplaced soon after the turbidite, would have probably dispersed the settling cloud. We envisage that a large debris flow associated with a thick turbidite, caused by instability around $185 \mathrm{ka}$, resulted in further instability in its source area and retrogressive sliding of displaced blocks from the basin margin into the basin. Previous to the emplacement of this slide complex, from 185 to $396 \mathrm{ka} \mathrm{(36.05-46.19}$ mbsf), redeposited sediments (mainly medium to thickly bedded clayey nannofossil ooze turbidites with basal sands but with one 1-m-thick, muddy, debris-flow deposit) were the main sediment type. However, deposition during this period was more sporadic, with one turbidite "event" (single thinly bedded turbidite or a small group of thinly bedded turbidites) occurring every 14 to $76 \mathrm{k}$.y. during a period of otherwise hemipelagic deposition.

Between $396 \mathrm{ka}$ and $0.9 \mathrm{Ma}(46.19-55.50 \mathrm{mbsf})$, sedimentation at Site 835 was predominantly hemipelagic in character, with only one thick-bedded turbidite emplaced during this period, at around $0.6 \mathrm{Ma}$ (in Section 135-835A-6H-1, $122 \mathrm{~cm}$, to $-6 \mathrm{H}-2,59 \mathrm{~cm}[48.72-$ $49.59 \mathrm{mbsf}]$ ). At around 1.0 Ma, another large slide complex was emplaced (56-71 mbsf; Fig. 17). The base of this sequence comprises a very thick mud turbidite with a thick basal foraminiferal sand (in Section $135-835 \mathrm{~A}-8 \mathrm{H}-2,141 \mathrm{~cm}$, to $-8 \mathrm{H}-4,42 \mathrm{~cm}[69.41-71.42$ mbsf]). This is directly overlain by a coherent $11-\mathrm{m}$-thick, rafted Pliocene hemipelagic block (in Section 135-835A-7H-1, $105 \mathrm{~cm}$, to $-8 \mathrm{H}-2,141 \mathrm{~cm}$ [58.05-69.41 mbsf]), which contains a thin mud-clast horizon between 66.4 and $66.6 \mathrm{mbsf}$. Directly overlying this is a thick muddy debris-flow deposit (in Section 135-835A-6H-6, $65 \mathrm{~cm}$, to $-7 \mathrm{H}-1,105 \mathrm{~cm}[55.50-58.05 \mathrm{mbsf}])$. The absence of any discernible intervening hemipelagic layers between these redeposited lithologies suggests that the elements of the slide complex were emplaced within a relatively short time of each other, and probably represent another episode of retrogressive sliding on part of the basin margin.

The time interval from 1.0 to $1.4 \mathrm{Ma}$ (from Section 135-835A-8H$4,42 \mathrm{~cm}$, to $-9 \mathrm{H}-2,19 \mathrm{~cm}$ [71.42-77.69 mbsf]) was again a period of quiet hemipelagic deposition at Site 835 . Around 1.4 Ma, a short period of instability began that lasted about 400 k.y. (77-87 mbsf; Fig. 17). During this period, several thin to very thick mud turbidites were emplaced with a depositional cyclicity of about one event every $23 \mathrm{k} . \mathrm{y}$. The period from 1.8 to $2.1 \mathrm{Ma}$ (in Section 135-835A-10H-1, $63 \mathrm{~cm}$, to $-10 \mathrm{H}-6,7 \mathrm{~cm}$ [86.13-92.92 mbsf]), was marked by almost exclusively hemipelagic sedimentation, with another episode of instability and emplacement of slide complexes commencing from 2.1 to $2.2 \mathrm{Ma}$.

Around $2.5 \mathrm{Ma}$, a very thick slide complex was emplaced (in Section 135-835A-11H-2, $62 \mathrm{~cm}$, to $-14 \mathrm{H}-4,25 \mathrm{~cm}$ [97.12-128.22 mbsf]; Figs. 17-18). This complex, which represents the main single depositional event in the basin since $3 \mathrm{Ma}$, consists of a very thick ( 8 m) basal muddy debris-flow deposit, directly overlain by a massive, $4-\mathrm{m}$-thick graded foraminiferal sand; this is overlain by $22 \mathrm{~m}$ of homogeneous mud, interpreted as the $T e$ mud division of a thick turbidite. Above this is a short interval of hemipelagic clayey nannofossil ooze representing a time interval of perhaps 7 k.y. (in Section $135-835 \mathrm{~A}-11 \mathrm{H}-2,50-62 \mathrm{~cm}[97.00-97.12 \mathrm{mbsf}])$. Above this lies a very thick $(4 \mathrm{~m})$ mud turbidite with a thin $(0.2 \mathrm{~m})$ basal foraminiferal sand (in Section 135-835A-10H-6, $7 \mathrm{~cm}$, to $-11 \mathrm{H}-2,50 \mathrm{~cm}[92.92$ $97.00 \mathrm{mbsf}]$ ).

Shipboard measurements of undrained shear strength identified three distinct geotechnical units within Unit I (Shipboard Scientific Party, 1992b) that broadly correlate with the lithologic sequence discussed above. The upper part of Unit $\mathrm{I}(0-45 \mathrm{mbsf})$ is characterized by low (generally less than $35 \mathrm{kPa}$ ) shear strengths. This broadly correlates with that part of the Brunhes Epoch marked by high amounts of redeposited material (see Fig. 17). Between 45 and about 
Table 2. Results of geochemical analysis by ICP-AES through Core 135-835A-1H (0-9.5 mbsf).

\begin{tabular}{|c|c|c|c|c|c|c|c|c|c|c|c|c|c|c|c|}
\hline $\begin{array}{l}\text { Core, section, } \\
\text { interval }(\mathrm{cm})\end{array}$ & $\begin{array}{l}\text { Depth } \\
\text { (mbsf) }\end{array}$ & $\begin{array}{c}\mathrm{Fe}_{2} \mathrm{O}_{3} \\
\text { (\%) }\end{array}$ & $\begin{array}{c}\mathrm{Al}_{2} \mathrm{O}_{3} \\
(\%)\end{array}$ & $\begin{array}{l}\mathrm{MnO} \\
(\%)\end{array}$ & $\begin{array}{l}\mathrm{MgO} \\
(\%)\end{array}$ & $\begin{array}{r}\mathrm{CaO} \\
(\%)\end{array}$ & $\begin{array}{c}\mathrm{Na} 2 \mathrm{O} \\
(\%)\end{array}$ & $\begin{array}{r}\mathrm{K}_{2} \mathrm{O} \\
(\%)\end{array}$ & $\begin{array}{l}\mathrm{TiO}_{2} \\
(\%)\end{array}$ & $\begin{array}{c}\text { As } \\
\text { (ppm) }\end{array}$ & $\begin{array}{c}\mathrm{Ba} \\
(\mathrm{ppm})\end{array}$ & $\begin{array}{c}\text { Co } \\
\text { (ppm) }\end{array}$ & $\begin{array}{c}\mathrm{Cr} \\
\text { (ppm) }\end{array}$ & $\begin{array}{c}\mathrm{Cu} \\
(\mathrm{ppm})\end{array}$ & $\begin{array}{c}\mathrm{Li} \\
\text { (ppm) }\end{array}$ \\
\hline \multicolumn{16}{|l|}{ 135-835A-1H- } \\
\hline $1 \mathrm{H}-1,18-20$ & 0.18 & 5.13 & 4.955 & 0.934 & 1.548 & 49.418 & 3.190 & 0.41 & 0.25 & 23 & 758 & 20 & 15 & 111 & 6 \\
\hline $1 \mathrm{H}-1,50-52$ & 0.50 & 6.65 & 6.020 & 0.882 & 1.740 & 31.030 & 3.270 & 0.52 & 0.31 & 25 & 589 & 20 & 15 & 110 & 7 \\
\hline $1 \mathrm{H}-1,75-77$ & 0.75 & 12.64 & 8.813 & 0.508 & 3.690 & 20.619 & 3.013 & 0.57 & 0.54 & 22 & 344 & 33 & 24 & 147 & 7 \\
\hline $1 \mathrm{H}-1,105-107$ & 1.05 & 4.96 & 4.980 & 0.927 & 1.420 & 37.050 & 3.460 & 0.48 & 0.23 & 25 & 566 & 17 & 13 & 102 & 6 \\
\hline $1 \mathrm{H}-1,135-137$ & 1.35 & 6.62 & 5.426 & 0.893 & 1.752 & 40.002 & 3.366 & 0.51 & 0.28 & 27 & 595 & 21 & 12 & 111 & 6 \\
\hline $1 \mathrm{H}-2,15-17$ & 1.65 & 6.13 & 5.114 & 0.979 & 1.618 & 46.887 & 3.408 & 0.50 & 0.27 & 24 & 593 & 20 & 11 & 112 & 6 \\
\hline $1 \mathrm{H}-2,25-27$ & 1.75 & 6.52 & 6.110 & 1.015 & 1.710 & 33.090 & 2.940 & 0.53 & 0.33 & 24 & 491 & 20 & 13 & 117 & 7 \\
\hline $1 \mathrm{H}-2,48-50$ & 1.98 & 5.90 & 5.950 & 1.269 & 1.590 & 33.680 & 3.190 & 0.48 & 0.27 & 27 & 596 & 20 & 14 & 135 & 8 \\
\hline $1 \mathrm{H}-2,77-79$ & 2.27 & 7.63 & 6.644 & 0.923 & 2.049 & 35.259 & 3.362 & 0.53 & 0.34 & 23 & 649 & 26 & 13 & 143 & 6 \\
\hline $1 \mathrm{H}-2,135-137$ & 2.85 & 6.47 & 6.232 & 1.254 & 1.895 & 42.845 & 2.968 & 0.46 & 0.29 & 28 & 624 & 22 & 14 & 144 & 7 \\
\hline $1 \mathrm{H}-3,7-9$ & 3.07 & 4.56 & 4.903 & 1.723 & 1.489 & 49.817 & 3.118 & 0.48 & 0.22 & 21 & 606 & 20 & 11 & 154 & 10 \\
\hline $1 \mathrm{H}-3,50-52$ & 3.50 & 4.25 & 4.871 & 1.715 & 1.466 & 49.440 & 2.897 & 0.46 & 0.21 & 36 & 567 & 21 & 10 & 218 & 9 \\
\hline $1 \mathrm{H}-3,65-67$ & 3.65 & 3.09 & 2.754 & 0.622 & 1.121 & 67.456 & 1.947 & 0.30 & 0.15 & 9 & 219 & 8 & 9 & 69 & 6 \\
\hline $1 \mathrm{H}-3,75-77$ & 3.75 & 4.64 & 5.225 & 1.815 & 1.512 & 49.809 & 3.047 & 0.50 & 0.23 & 29 & 616 & 22 & 10 & 146 & 8 \\
\hline $1 \mathrm{H}-3,138-140$ & 4.38 & 4.63 & 5.153 & 1.853 & 1.488 & 48.166 & 2.900 & 0.48 & 0.23 & 37 & 602 & 21 & 14 & 142 & 8 \\
\hline $1 \mathrm{H}-4,18-20$ & 4.68 & 4.86 & 5.304 & 1.928 & 1.523 & 49.337 & 3.026 & 0.50 & 0.24 & 32 & 608 & 22 & 7 & 147 & 8 \\
\hline $1 \mathrm{H}-4,75-77$ & 5.25 & 4.65 & 5.306 & 2.170 & 1.568 & 49.636 & 2.929 & 0.49 & 0.23 & 31 & 617 & 22 & 12 & 146 & 8 \\
\hline $1 \mathrm{H}-4,135-137$ & 5.85 & 4.73 & 5.321 & 1.761 & 1.536 & 50.337 & 2.928 & 0.49 & 0.24 & 38 & 603 & 22 & 12 & 141 & 8 \\
\hline IH-5, 18-20 & 6.08 & 4.79 & 5.386 & 1.778 & 1.550 & 50.999 & 2.849 & 0.50 & 0.24 & 35 & 600 & 22 & 10 & 143 & 8 \\
\hline $1 \mathrm{H}-5,75-77$ & 6.65 & 4.76 & 5.260 & 1.762 & 1.528 & 50.202 & 2.905 & 0.50 & 0.23 & 25 & 572 & 20 & 14 & 140 & 8 \\
\hline IH- $5,120-122$ & 7.10 & 4.47 & 5.220 & 1.655 & & & 2.910 & 0.50 & 0.22 & 28 & 509 & & 10 & 137 & \\
\hline IH-5, 135-137 & 7.25 & 4.71 & 5.106 & 1.670 & 1.516 & 50.162 & 2.872 & 0.49 & 0.23 & 40 & 548 & 20 & 14 & 136 & 8 \\
\hline $1 \mathrm{H}-6,8-9$ & 7.48 & 4.47 & 4.249 & 1.203 & 1.385 & 52.797 & 2.674 & 0.43 & 0.21 & 21 & 414 & 16 & 8 & 107 & 7 \\
\hline $1 \mathrm{H}-6,15-17$ & 7.55 & 3.95 & 3.680 & 0.862 & 1.140 & 43.160 & 2.150 & 0.38 & 0.18 & 18 & 288 & 11 & 10 & 80 & 7 \\
\hline $1 \mathrm{H}-6,25-27$ & 7.65 & 3.85 & 3.280 & 0.689 & 1.090 & 43.160 & 2.410 & 0.39 & 0.17 & 11 & 243 & 9 & 10 & 68 & 6 \\
\hline IH- $6,41-43$ & 7.81 & 3.18 & 2.924 & 0.649 & 1.190 & 41.930 & 2.388 & 0.34 & 0.06 & 10 & 224 & 9 & 10 & 68 & 7 \\
\hline IH-6. 70-72 & 8.10 & 3.30 & 2.910 & 0.582 & 0.980 & 45.060 & 2.290 & 0.35 & 0.16 & 12 & 195 & 7 & 11 & 61 & 6 \\
\hline $1 \mathrm{H}-6,94-96$ & 8.34 & 8.90 & 6.567 & 0.841 & 2.278 & 35.957 & 2.721 & 0.52 & 0.35 & 23 & 335 & 20 & 17 & 128 & 7 \\
\hline 1H-6, 105-107 & 8.45 & 3.01 & 4.506 & 2.221 & 1.383 & 57.833 & 2.407 & 0.42 & 0.17 & 35 & 389 & 15 & 8 & 166 & 9 \\
\hline $1 \mathrm{H}-7,15-17$ & 9.05 & 3.88 & 3.996 & 1.564 & 1.484 & 60.196 & 2.127 & 0.41 & 0.23 & 22 & 466 & 22 & 12 & 100 & 13 \\
\hline 1H-CC, 17-19 & 9.43 & 4.25 & 4.189 & 1.443 & 1.521 & 54.307 & 2.501 & 0.52 & 0.23 & 36 & 438 & 20 & 12 & 116 & 15 \\
\hline
\end{tabular}

90 mbsf, shear strengths are about $45 \mathrm{kPa}$, but display considerable scatter. These values were interpreted as representing a more consolidated section of the sediment column (Shipboard Scientific Party, 1992b). This interval correlates with an interval dominated by hemipelagic sedimentation, where the main type of allochthonous sediments consists of coherent rafted hemipelagic blocks. Below $95 \mathrm{mbsf}$, shear strengths increase from about $45 \mathrm{kPa}$ to about $100 \mathrm{kPa}$, indicating a rapid increase in sediment strength. However, measurements made through the mud interval from 95 to 117 mbsf gave consistent values, with the marked increase in shear strength beginning at around $122 \mathrm{mbsf}$ (the upper boundary of a thick muddy debris-flow deposit) and increasing further in the volcaniclastic-rich Lithologic Unit II (133-156 mbsf).

\section{THICK SLIDE COMPLEX EMPLACED AT ABOUT 2.5 MA}

Division of the sediment sequence into genetic units (from the sedimentologic criteria discussed above) suggests that the interval from 97.12 to 128.22 mbsf comprises a thick slide complex made up of a thick muddy debrite (121.45-128.22 mbsf) and overlying thick turbidite mud with basal foraminiferal sand (97.12-121.45 mbsf). The interval from 97.12 to $117.35 \mathrm{mbsf}$ is a very thick $T e$-division turbidite mud that appears to be a single unit (Figs. 17-18). The mud is a uniform dark yellowish brown (10YR 4/2) and appears completely homogeneous. The interval contains no pumice clast dropstones, and large planktonic foraminifers are very rare or absent. Sieving of samples from this mud through a $63-\mu \mathrm{m}$ mesh show very small retained residues ( $1 \%$ or less) consisting of small juvenile foraminifers or broken-up, comminuted test fragments. This mud grades into a very poorly sorted, muddy structureless foraminiferal silty sand at 117 to $118 \mathrm{mbsf}$, which grades downcore into massive, graded foraminiferal sand. The foraminiferal sand bed is $4 \mathrm{~m}$ thick and has been interpreted as a sandy base to the overlying thick turbiditic mud. Grain-size profiles through this whole unit (Fig. 19) show that the thick turbiditic mud is largely devoid of sand, and the median grain size and silt/clay ratios are fairly constant over a vertical thickness of $20 \mathrm{~m}$. The percentage of silt and clay throughout this interval shows some variation (Fig. 19). This may possibly be the result of reflection and backwash of the large-volume sediment gravity flow when it was emplaced in the relatively small constricted basin, which resulted in repeated rebounding from the basin walls, leading to residual sloshing in the turbidite mud cloud. Van Andel and Komar (1969) interpreted similar grain-size data from ponded biogenic turbidites as possibly representing reflected flow and repeated rebound from basin walls; flow reflection within turbidites emplaced in confined basins is an increasingly recognized phenomenon (Einsele and Kelts, 1982; Pickering and Hiscott, 1985; Pantin and Leeder, 1987; Porebski et al., 1991). Stacked grain-size spectra from this thick mud (Fig. 20) show that the turbidite mud has a remarkably constant primary mode of around $7.5 \phi(5.5 \mu \mathrm{m})$. This coccolith primary mode remains constant over a vertical thickness of $20 \mathrm{~m}$, although a brief shift to a finer primary mode is seen for a short interval from 113 to $115 \mathrm{mbsf}$ (Fig. 20). This may be an effect of flow reflection following containment of the flow within the basin. Within the mud, sand/coarse silt modes are rare or absent, although below $117 \mathrm{mbsf}$ the sediment grades into foraminiferal sand.

Downcore geochemical profiles at Site 835 typically show variable values (Fig. 21). However, high-resolution geochemical profiling shows that clayey nannofossil ooze hemipelagites generally have highly variable elemental concentrations, in some cases caused by variation in hydrothermal fluxes through time (Hodkinson and Cronan, this volume). In contrast, vertical geochemical profiles of particular elements within single turbidite beds are typically straight, showing that element concentrations throughout single turbidites are fairly constant, even over several meters (see Figs. 10-11). Downcore geochemical profiles at Site 835 show remarkably constant values for all major and minor elements in the interval from 97 to $117 \mathrm{mbsf}$ (e.g., Fig. 21), suggesting that our interpretation of this interval (that it comprises a single thick turbidite mud) may be correct.

Compressional velocity measured by the $P$-wave logger shows a prominent peak of increased velocity from 117 to $122 \mathrm{mbsf}$ (Fig. 22). This correlates with a thick foraminiferal sand at the base of the thick clayey nannofossil ooze turbidite. Velocities are relatively constant through the interval from 97 to 117 mbsf, compared with those obtained throughout the rest of the hole, and the total $P$-wave record in the interval from 97 to 122 mbsf is strongly reminiscent of that obtained in the turbidite muds that have sandy bases. 
Table 2 (continued).

\begin{tabular}{|c|c|c|c|c|c|c|c|c|}
\hline $\begin{array}{c}\mathrm{Ni} \\
\text { (ppm) }\end{array}$ & $\begin{array}{c}\mathrm{Pb} \\
(\mathrm{ppm})\end{array}$ & $\begin{array}{c}\mathrm{Sc} \\
(\mathrm{ppm})\end{array}$ & $\begin{array}{c}\mathrm{Sr} \\
(\mathrm{ppm})\end{array}$ & $\begin{array}{c}\mathrm{Y} \\
\text { (ppm) }\end{array}$ & $\underset{(\mathrm{ppm})}{\mathrm{Zn}}$ & $\begin{array}{c}\mathrm{Zr} \\
(\mathrm{ppm})\end{array}$ & $\begin{array}{c}\mathrm{P}_{2} \mathrm{O}_{5} \\
(\%)\end{array}$ & $\begin{array}{c}\mathbf{V} \\
(\mathrm{ppm})\end{array}$ \\
\hline 43 & 20 & 14 & 1506 & 36 & 76 & 32 & 0.30 & 120 \\
\hline 39 & 18 & 19 & 1154 & 38 & 67 & 43 & 0.20 & 151 \\
\hline 36 & 9 & 39 & 553 & 27 & 98 & 39 & 0.20 & 272 \\
\hline 38 & 24 & 14 & 1418 & 39 & 60 & 38 & 0.22 & 116 \\
\hline 37 & 17 & 17 & 1220 & 34 & 75 & 33 & 0.27 & 134 \\
\hline 44 & 18 & 15 & 1366 & 39 & 74 & 36 & 0.28 & 126 \\
\hline 44 & 22 & 18 & 1199 & 42 & 73 & 49 & 0.22 & 154 \\
\hline 55 & 26 & 17 & 1346 & 41 & 77 & 49 & 0.22 & 154 \\
\hline 35 & 17 & 22 & 1070 & 39 & 86 & 36 & 0.28 & 187 \\
\hline 51 & 23 & 20 & 1264 & 43 & 92 & 38 & 0.31 & 159 \\
\hline 77 & 27 & 12 & 1547 & 41 & 92 & 24 & 0.33 & 127 \\
\hline 75 & 30 & 11 & 1495 & 38 & 90 & 21 & 0.32 & 129 \\
\hline 27 & 5 & 8 & 1360 & 22 & 47 & 26 & 0.20 & 69 \\
\hline 76 & 30 & 12 & 1563 & 41 & 91 & 12 & 0.33 & 145 \\
\hline 72 & 29 & 12 & 1542 & 41 & 93 & 39 & 0.33 & 143 \\
\hline 75 & 35 & 13 & 1577 & 42 & 97 & 40 & 0.34 & 148 \\
\hline 78 & 33 & 12 & 1589 & 42 & 95 & 16 & 0.33 & 147 \\
\hline 72 & 32 & 13 & 1615 & 42 & 93 & 11 & 0.33 & 149 \\
\hline 72 & 30 & 13 & 1617 & 43 & 94 & 29 & 0.34 & 148 \\
\hline 71 & 31 & 13 & 1572 & 42 & 92 & 39 & 0.34 & 148 \\
\hline 73 & 33 & 12 & 1562 & 41 & 83 & 42 & & \\
\hline 69 & 29 & 12 & 1536 & 42 & 90 & 30 & 0.33 & 143 \\
\hline 52 & 20 & 12 & 1414 & 39 & 71 & 29 & 0.30 & 118 \\
\hline 38 & 15 & 11 & 1371 & 37 & 51 & 36 & & 96 \\
\hline 33 & 12 & 11 & 1299 & 36 & 46 & 37 & & 81 \\
\hline 31 & 14 & 6 & 1046 & 18 & 52 & 20 & 0.32 & 73 \\
\hline 28 & 9 & 8 & 1330 & 23 & 40 & 33 & & 66 \\
\hline 42 & 12 & 24 & 935 & 25 & 85 & 37 & 0.23 & 180 \\
\hline 91 & 28 & 8 & 1714 & 38 & 99 & 12 & 0.32 & 134 \\
\hline 42 & 26 & 11 & 1516 & 45 & 65 & 37 & 0.33 & 101 \\
\hline 41 & 26 & 12 & 1436 & 43 & 73 & 33 & 0.31 & 109 \\
\hline
\end{tabular}

Our lithologic interpretation over the interval from 90 to $130 \mathrm{mbsf}$ shows good correlation with downhole resistivity and standard gammaray and bulk density logs (Fig. 23). The hemipelagic clayey nannofossil oozes show a distinctly higher resistivity than the turbiditic clayey nannofossil oozes. Resistivity throughout the thick turbidite mud between 97 and $117 \mathrm{mbsf}$ is fairly constant, suggesting homogeneity throughout this interval (Fig. 23). Resistivity increases in the thick foraminiferal sand that lies at the base of the turbidite mud. The standard gamma-ray log shows higher values in the hemipelagic clayey nannofossil oozes and lower values in the turbiditic clayey nannofossil oozes. Gamma-ray log values increase markedly in the upper part of the mud-clast conglomerate lying from 121.35 to $128.22 \mathrm{mbsf}$, and the range of values through the overlying turbidite (97.12-121.45 mbsf) is restricted. The bulk density log shows slightly higher values in the hemipelagites compared to the turbidites. Bulk density increases in the basal foraminiferal sand from 117.35 to $121.35 \mathrm{mbsf}$, while the normal grading within the sand is readily apparent.

The downhole Schlumberger Formation MicroScanner (FMS) borehole image over the interval from 90 to 130 mbsf shows a clear correlation with lithology. The foraminiferal sands from 96.80 to 97.00 and from 117.35 to 121.45 mbsf appear as whitish bands of equivalent thickness. The homogeneous turbidite mud from 92.92 to $96.80 \mathrm{mbsf}$ shows as a distinct dark band that becomes mottled toward its top (92.92-94.50 mbsf), probably reflecting bioturbation. However, the thick homogeneous turbidite mud from 97.12 to 117.35 mbsf, although darker than hemipelagic intervals on the FMS log, appears variously mottled throughout. This is artificial and merely reflects the expanded range of gray scales within the darker mud interval and occasional poor pad contact.

The boundary between the mud-clast conglomerate and the underlying sediment at $128.22 \mathrm{mbsf}$ is clearly eroded. The base of the mud-clast conglomerate dips by about $52^{\circ}$ to the east (C. MacLeod, pers. comm., 1992). The steepness of this contact suggests that it may be part of a basal scour.

Shipboard paleomagnetic measurements (Shipboard Scientific Party, 1992b) suggest that this large slide complex was emplaced between the top of the Gauss normal geomagnetic Epoch (2.48 Ma) and the top of the Kaena Subchron (2.92 Ma). Indeed, the entire sequence corresponding to this geomagnetic interval (93-128 mbsf;
Fig. 17) appears to comprise the large slide complex (thick mud-clast conglomerate, overlain by very thick mud turbidite; $97-128 \mathrm{mbsf}$ ), a thin pelagic layer ( $97.00-97.12 \mathrm{mbsf}$ ), and another thick-bedded mud turbidite with basal foraminiferal sand (92.92-96.80 mbsf; Figs. 17-18). The interval between the top of the Gauss Epoch and the top of the Kaena Subchron represents about 0.44 Ma. Assuming an average hemipelagic sedimentation rate of $1.44 \mathrm{~cm} / \mathrm{k} . \mathrm{y}^{-1}$, then the pelagic layer, $12 \mathrm{~cm}$ thick, identified in this depositional interval represents only $8 \mathrm{k} . \mathrm{y}$.

We can consider two possible scenarios to explain this sequence:

1. Possibly, the thick turbidite unit and mud-clast conglomerate acquired a normal polarity and the slide complex was emplaced in the lower part of the Matuyama Epoch at around 2.2 Ma. An emplacement age of $2.2 \mathrm{Ma}$ is suggested by consideration of average sedimentation rates and the amount of hemipelagic sediment deposited above the complex and by the sedimentation rate curves. Were this interpretation correct, then the magnetostratigraphy in this part of the hole would need revision. A turbidite should record the ambient field direction when it was emplaced. If the sediment were very coarse, then it would probably not be a good recorder (i.e., the inclination could be shallower than expected and movement of grains could confuse the declination). Further, if the turbidite mud were very unconsolidated, then it is conceivable that the sediment could receive an overprint field from the drill string that would tend to make the magnetization appear normal polarity (W.W. Sager, pers. comm., 1992). However, no evidence is present that the turbidite mud is underconsolidated and indeed, it appears quite firm. Consequently, we consider this explanation to be unlikely.

2. It is possible that the thick debris flow at the base of the slide complex might have eroded, perhaps substantially, the underlying pelagic nannofossil ooze, which at the time of emplacement may have been less consolidated. About $6 \mathrm{~m}$ of hemipelagic sediment would need to be eroded to account for the missing hemipelagic interval, which represents about 430 k.y. The eroded sediment might have formed a cloud of suspended material in front of the advancing debris flow, whose movement may have been abnormally high considering the very steep gradients over which it traveled during emplacement. The material in this cloud may have been deposited to the north, where the basin is slightly deeper and wider. The eroded material thus may have been deposited to the north or perhaps, if the volume of the slide were large, at least part of the suspended eroded hemipelagic material may have become incorporated into the main body of the turbidity current cloud, which was emplaced on top of the debris flow, assuming the turbidity current was emplaced very soon after or at the same time as the debris flow. The eroded hemipelagic grains may have settled out in the turbidity current cloud and become incorporated into the settling turbidite mud. Considering the lithologic and geochemical evidence and the paleomagnetic data, we consider this to be the most likely scenario.

\section{TECTONIC CONTROL OF SEDIMENTATION AT SITES 834 AND 835}

Parson and Hawkins (this volume) show that the propagating ridge that formed the East Lau Spreading Center passed the latitude of Sites 834 and 835 at around $3.6 \mathrm{Ma}$ and that the propagator that formed the Central Lau Spreading Center passed the latitude of the two sites from about 0.5 to $0.6 \mathrm{Ma}$. Sedimentation at Site 834 at $3.6 \mathrm{Ma}$ was dominated by deposition of thick epiclastic volcanic sands and silts, which were interbedded with hemipelagic nannofossil clays and mixed sediments (Shipboard Scientific Party, 1992a). The passing of the East Lau propagator occurred close to the transition between Lithologic Units II and III at Site 834. The boundary between Lithologic Units II and III marks a perceived decrease in the thickness and frequency of volcaniclastic turbidites (Shipboard Scientific Party, 1992a). However, close to this boundary, an episode of increased 

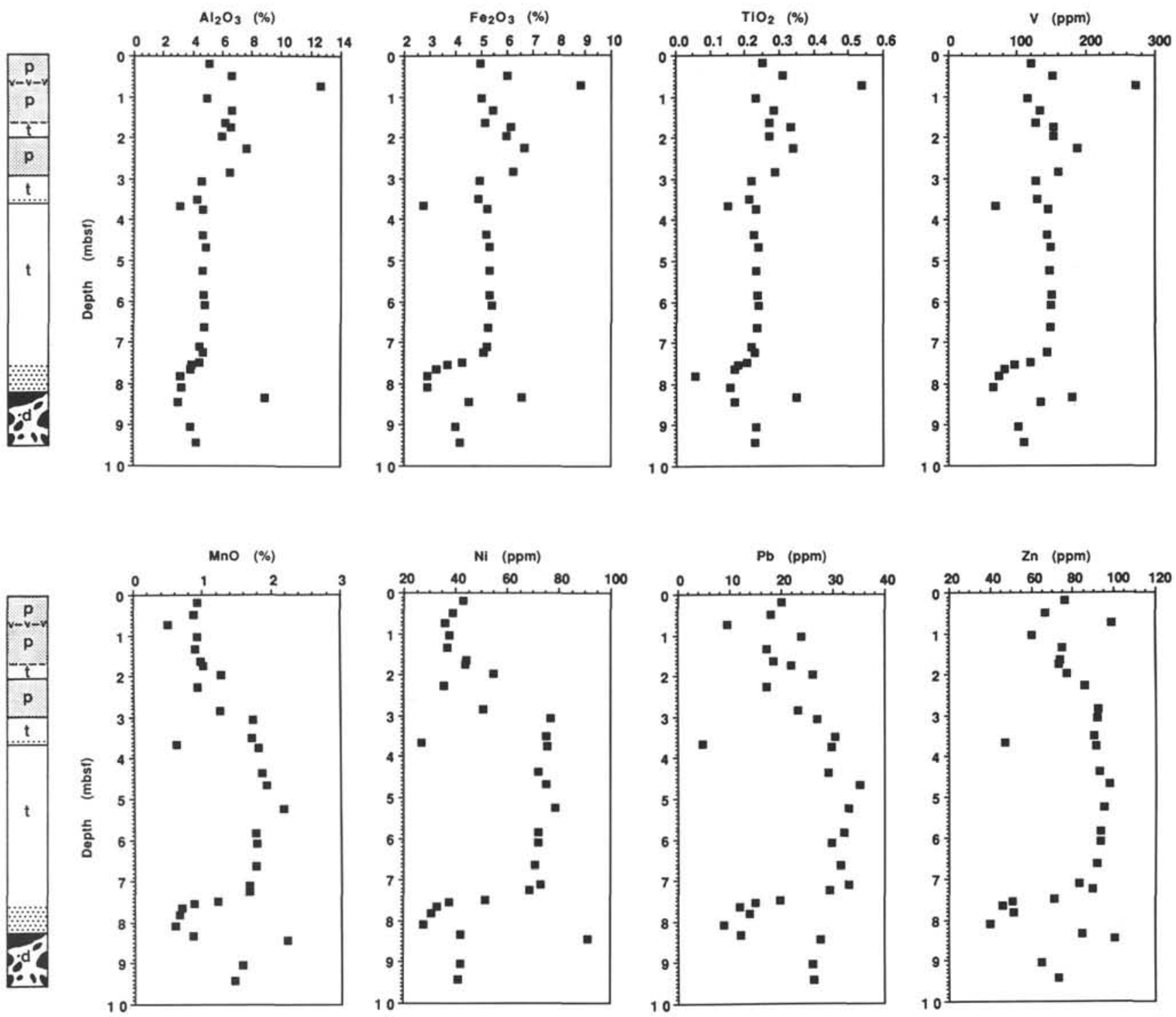

Figure 10. Graphic log of Core 135-835A-1H (0-9.5 mbsf) with downcore geochemical profiles plotted alongside. Note the variability in the hemipelagic intervals compared to the turbidite muds, which show consistent values throughout and are enriched in $\mathrm{Mn}, \mathrm{Ni}, \mathrm{Pb}$, and $\mathrm{Zn}$. See Figure 6 caption for key to graphic log of core.

sandy turbidite deposition is marked by two "packets" of stacked turbidites, with several turbidites emplaced directly one on top of one another, with little or no intervening hemipelagic deposition between the individual turbidites. The first of these occurs at about $3.5 \mathrm{Ma}$, and the second at about $3.9 \mathrm{Ma}$. The increase in frequency and "sandiness" of volcaniclastic turbidites at these times may possibly correlate with increased instability caused by the approach and passing of the East Lau propagator. The oceanic crust that forms the floor of the basin in which Site 835 was drilled is about $3.6 \mathrm{Ma}$ old (Shipboard Scientific Party, 1992b).

Between $2.4 \mathrm{Ma}$ and $200 \mathrm{ka}$, a marked decrease in frequency of turbidite emplacement can be seen at Site 834, with turbidites becoming very rare and typically thinly bedded when they do occur. This interval corresponds with a period of predominantly hemipelagic deposition and may mark the tectonically "quiet" period between the approach and passing of the East Lau and Central Lau propagators (Fig. 24).

Deposition over the last 3 m.y. at Site 835, in contrast to Site 834, has been dominated by redeposited sediments, and four main episodes of instability can be identified at this site. These occurred from 0 to $0.4,0.9$ to $1.0,1.4$ to 1.7 , and 2.1 to $2.9 \mathrm{Ma}$ and involved catastrophic slope failures with the emplacement of thick muddy debris flows, which often carried large rafted blocks and thick mud turbidites (Fig. 24). The reason for these periods of instability are as yet unknown, but the most recent episode $(0-0.4 \mathrm{Ma})$ may relate to tectonic activity and crustal readjustment following the passing of the Central Lau propagator at around $0.5 \mathrm{Ma}$.

\section{CONCLUSIONS}

Sites 834 and 835 show a similar sediment sequence that consists of clayey nannofossil oozes and mixed sediments interbedded with epiclastic vitric sands and silts. Clayey nannofossil oozes are the predominant sediment type deposited over the last $3 \mathrm{Ma}$. In the upper Pliocene to Pleistocene section at Site 835, the clayey nannofossil ooze sequence is anomalously thick and much of it has been redeposited.

Redeposited clayey nannofossil oozes can be distinguished from hemipelagic nannofossil oozes from several sedimentological criteria, including variation in color hue and chroma, presence or absence of bioturbation, presence or absence of scattered foraminifers, grain-size characteristics, variability in calcium carbonate content, presence or absence of pumice clasts, and micropaleontology. Clayey nannofossil ooze turbidites and hemipelagites are also geochemically distinct. 
Table 3. Results of geochemical analysis by ICP-AES through Sections 135-835A-10H-1 to $-11 \mathrm{H}-2$ (85-98 mbsf).

\begin{tabular}{|c|c|c|c|c|c|c|c|c|c|c|c|c|c|c|c|c|c|c|c|c|c|c|c|c|}
\hline $\begin{array}{l}\text { Core, section, } \\
\text { interval }(\mathrm{cm})\end{array}$ & $\begin{array}{l}\text { Depth } \\
\text { (mbsf) }\end{array}$ & $\begin{array}{l}\mathrm{Al}_{2} \mathrm{O}_{3} \\
(\%)\end{array}$ & $\begin{array}{l}\mathrm{Fe}_{2} \mathrm{O}_{3} \\
(\%)\end{array}$ & $\begin{array}{l}\mathrm{MnO} \\
(\%)\end{array}$ & $\begin{array}{l}\mathrm{MgO} \\
(\%)\end{array}$ & $\begin{array}{l}\mathrm{CaO} \\
(\%)\end{array}$ & $\begin{array}{l}\mathrm{Na}_{2} \mathrm{O} \\
(\%)\end{array}$ & $\begin{array}{l}\mathrm{K}_{2} \mathrm{O} \\
(\%)\end{array}$ & $\begin{array}{l}\mathrm{TiO}_{2} \\
(\%)\end{array}$ & $\begin{array}{c}\text { As } \\
(\mathrm{ppm})\end{array}$ & $\begin{array}{c}\mathrm{Ba} \\
(\mathrm{ppm})\end{array}$ & $\begin{array}{c}\text { Co } \\
(\mathrm{ppm})\end{array}$ & $\begin{array}{c}\mathrm{Cr} \\
(\mathrm{ppm})\end{array}$ & $\begin{array}{c}\mathrm{Cu} \\
(\mathrm{ppm})\end{array}$ & $\underset{(\mathrm{ppm})}{\mathrm{Li}}$ & $\begin{array}{c}\mathrm{Ni} \\
(\mathrm{ppm})\end{array}$ & $\begin{array}{c}\mathrm{Pb} \\
(\mathrm{ppm})\end{array}$ & $\begin{array}{c}\mathrm{Sc} \\
(\mathrm{ppm})\end{array}$ & $\begin{array}{c}\mathrm{Sr} \\
(\mathrm{ppm})\end{array}$ & $\begin{array}{c}\mathrm{Y} \\
(\mathrm{ppm})\end{array}$ & $\begin{array}{c}\mathrm{Zn} \\
(\mathrm{ppm})\end{array}$ & $\begin{array}{c}\mathrm{Zr} \\
(\mathrm{ppm})\end{array}$ & $\begin{array}{l}\mathrm{P}_{2} \mathrm{O}_{5} \\
(\%)\end{array}$ & $\begin{array}{c}\mathrm{V} \\
(\mathrm{ppm})\end{array}$ \\
\hline \multicolumn{25}{|l|}{$135-835 \mathrm{~A}-$} \\
\hline $10 \mathrm{H}-1,18-20$ & 85.68 & 3.788 & 4.840 & 2.312 & 1.319 & 53.534 & 2.371 & 0.521 & 0.219 & 31 & 534 & 24 & 14 & 150 & 11 & 106 & 33 & 10 & 1795 & 41 & 96 & 38 & 0.34 & 153 \\
\hline $10 \mathrm{H}-1,60-62$ & 86.10 & 8.815 & 6.883 & 0.347 & 2.364 & 30.961 & 3.433 & 0.963 & 0.415 & 18 & 367 & 8 & 27 & 321 & 23 & 48 & 13 & 17 & 750 & 15 & 134 & 49 & 0.18 & 80 \\
\hline $10 \mathrm{H}-1,68-70$ & 86.18 & 3.849 & 4.186 & 0.954 & 1.244 & 57.078 & 2.214 & 0.433 & 0.217 & 30 & 406 & 12 & 10 & 122 & 10 & 75 & 27 & 10 & 1763 & 41 & 63 & 32 & 0.28 & 108 \\
\hline $10 \mathrm{H}-1,130-132$ & 86.80 & 3.804 & 4.499 & 1.396 & 1.311 & 58.591 & 2.222 & 0.391 & 0.232 & 31 & 528 & 22 & 7 & 144 & 11 & 85 & 36 & 9 & 1856 & 47 & 77 & 19 & 0.32 & 125 \\
\hline $10 \mathrm{H}-2,15-17$ & 87.15 & 3.504 & 4.142 & 1.809 & 1.251 & 59.460 & 2.066 & 0.396 & 0.218 & 24 & 451 & 28 & 9 & 135 & 10 & 96 & 31 & 9 & 18 & 40 & 81 & 36 & 0.30 & 119 \\
\hline $10 \mathrm{H}-2,71-73$ & 87.71 & 3.892 & 4.627 & 1.985 & 1.412 & 59.151 & 2.232 & 0.444 & 0.234 & 27 & 562 & 24 & 9 & 14 & 12 & 97 & 3. & 11 & 18 & 46 & 91 & 18 & 0.31 & 129 \\
\hline $10 \mathrm{H}-2,140-142$ & 8.40 & 4.490 & 5.535 & 2.694 & 1.499 & 47.359 & 2.443 & 0.579 & 0.259 & 37 & 572 & 28 & 16 & 16 & 12 & 125 & 44 & 11 & 1666 & 47 & 109 & 42 & 0.35 & 168 \\
\hline $10 \mathrm{H}-3,20-22$ & 88.70 & 8.346 & 5.541 & 0.601 & 2.665 & 31.812 & 3.015 & 0.577 & 0.379 & 7 & 269 & 7 & 11 & 273 & 29 & 50 & 21 & 17 & 1054 & 38 & 133 & 61 & 0.20 & 53 \\
\hline $10 \mathrm{H}-3,32-34$ & 88.82 & 3.878 & 4.214 & 1.887 & 1.295 & 53.282 & 2.187 & 0.497 & 0.219 & 41 & 455 & 24 & 9 & 112 & 11 & 90 & 32 & 10 & 1792 & 44 & 84 & 35 & 0.30 & 117 \\
\hline $10 \mathrm{H}-3,135-137$ & 89.85 & 3.116 & 4.190 & 2.327 & 1.173 & 58.322 & 1.858 & 0.283 & 0.193 & 30 & 481 & 22 & 14 & 143 & 9 & 112 & 38 & 8 & 1817 & 40 & 82 & 34 & 0.35 & 129 \\
\hline $10 \mathrm{H}-4,25-27$ & 90.25 & 3.314 & 4.471 & 2.390 & 1.281 & 59.441 & 2.047 & 0.394 & 0.201 & 29 & 498 & 22 & 14 & 139 & 9 & 114 & 35 & 8 & 1838 & 50 & 87 & 38 & 0.34 & 136 \\
\hline $\mathrm{H}-4,60-62$ & 0.60 & 3.412 & 4.800 & 2.484 & 1.222 & 53.768 & 2.045 & 0.392 & 0.200 & 35 & 643 & 23 & 15 & 15 & 9 & 129 & 39 & 8 & 1837 & 58 & 98 & 38 & 0.33 & 149 \\
\hline$-4,92-94$ & 0.92 & 8.953 & 5.831 & 0.361 & 2.643 & 27.837 & 3.361 & 0.648 & 0.395 & 8 & 248 & 7 & 8 & 20 & 27 & 41 & 21 & 19 & 8 & 41 & 133 & 56 & 0.20 & 93 \\
\hline & & 3.175 & 4.619 & 2.489 & 1.217 & 59.735 & 2.046 & & & 44 & 559 & 24 & 11 & 11 & 8 & 117 & 37 & 8 & 1914 & 49 & 90 & 39 & 0.3 & 139 \\
\hline $10 \mathrm{H}-5,75-77$ & 92.11 & 5.891 & 5.897 & 1.348 & 2.002 & 43.430 & 2.740 & 0.464 & 0.30 & 35 & 528 & 18 & 12 & 16 & 14 & 74 & 30 & 15 & 1491 & 47 & 101 & 42 & 0.29 & 124 \\
\hline H-5, 135-137 & 92.71 & 3.940 & 4.699 & 1.627 & 1.357 & 56.585 & 2.400 & 0.338 & 0.22 & 2 & 470 & 19 & 10 & 13 & 9 & 64 & 28 & 11 & 180 & 40 & 79 & 18 & 0.29 & 117 \\
\hline 6,17 & 93.0 & 3.938 & 5.820 & 3.0 & 1.407 & 51.2 & 2.5 & 0.5 & 0.2 & 5 & 545 & 24 & 17 & 18 & 8 & 116 & 42 & 10 & 18 & 39 & 120 & 38 & 0.39 & 188 \\
\hline & 93.6 & 4.03 & 5.921 & 2.9 & 1.44 & 53.0 & 2.4 & 0.5 & 0.2 & 45 & 540 & 21 & 18 & 17 & 8 & 106 & 38 & 10 & 18 & 40 & 119 & 42 & 0.40 & 172 \\
\hline-137 & 4.21 & 4.023 & 5.801 & 2.59 & 1.432 & 52.6 & 2.66 & 0.497 & 0.22 & 4 & 509 & 20 & 18 & 17 & 8 & 99 & 40 & 10 & 18 & 40 & 114 & 40 & 0.38 & 169 \\
\hline $10 \mathrm{H}-7,1$ & 94.51 & 4.001 & 5.538 & 2.467 & 1.350 & 50.769 & 2.768 & 0.464 & 0.21 & & 511 & 20 & 17 & 17 & 8 & 100 & 36 & 10 & 18 & 39 & 111 & 31 & 0.37 & 161 \\
\hline $10 \mathrm{H}-7$, & 94.91 & 3.810 & 5.504 & 2.473 & 1.356 & 51.029 & 2.609 & 0.424 & 0.21 & 4 & 503 & 19 & 15 & 17 & 7 & 99 & 36 & 10 & 18 & 38 & 111 & 23 & 0.36 & 160 \\
\hline & & 3.97 & 5.66 & & 1.360 & 51.2 & 2.5 & 0.4 & 0.2 & & 50 & & 18 & 17 & 8 & 103 & 4 & i & 18 & 38 & 30 & 40 & 0.3 & 166 \\
\hline & & 4.209 & & 2.4 & 1.3 & 49. & 2.7 & & & 3 & 4 & & 17 & 17 & 8 & 9 & 3 & & & & & & 0. & 160 \\
\hline & & & & & 1.3 & & & & & 3 & 50 & 2 & 17 & 17 & 7 & 10 & 3 & 10 & & 38 & 112 & 4 & & 161 \\
\hline & & 4.0 & 5.72 & 2.6 & 1.3 & 52.4 & 2.8 & 0.4 & 0.2 & 5 & 51 & 21 & 11 & 18 & 8 & 106 & 39 & 10 & 18 & 39 & 121 & 29 & 0.38 & 168 \\
\hline $11 \mathrm{H}-2,44-46$ & 6.94 & 3.189 & 3.215 & 0.992 & 1.134 & 63.284 & 2.475 & 0.307 & 0.160 & 19 & 278 & 8 & 11 & 92 & 5 & 42 & 12 & 8 & 1548 & 34 & 60 & 19 & 0.28 & 86 \\
\hline $11 \mathrm{H}-2,58-60$ & 97.08 & 4.349 & 5.640 & 1.715 & 1.523 & 54.424 & 2.744 & 0.468 & 0.244 & 39 & 491 & 15 & 11 & 165 & 9 & 89 & 39 & 11 & 1841 & 39 & 105 & 15 & 0.33 & 146 \\
\hline
\end{tabular}



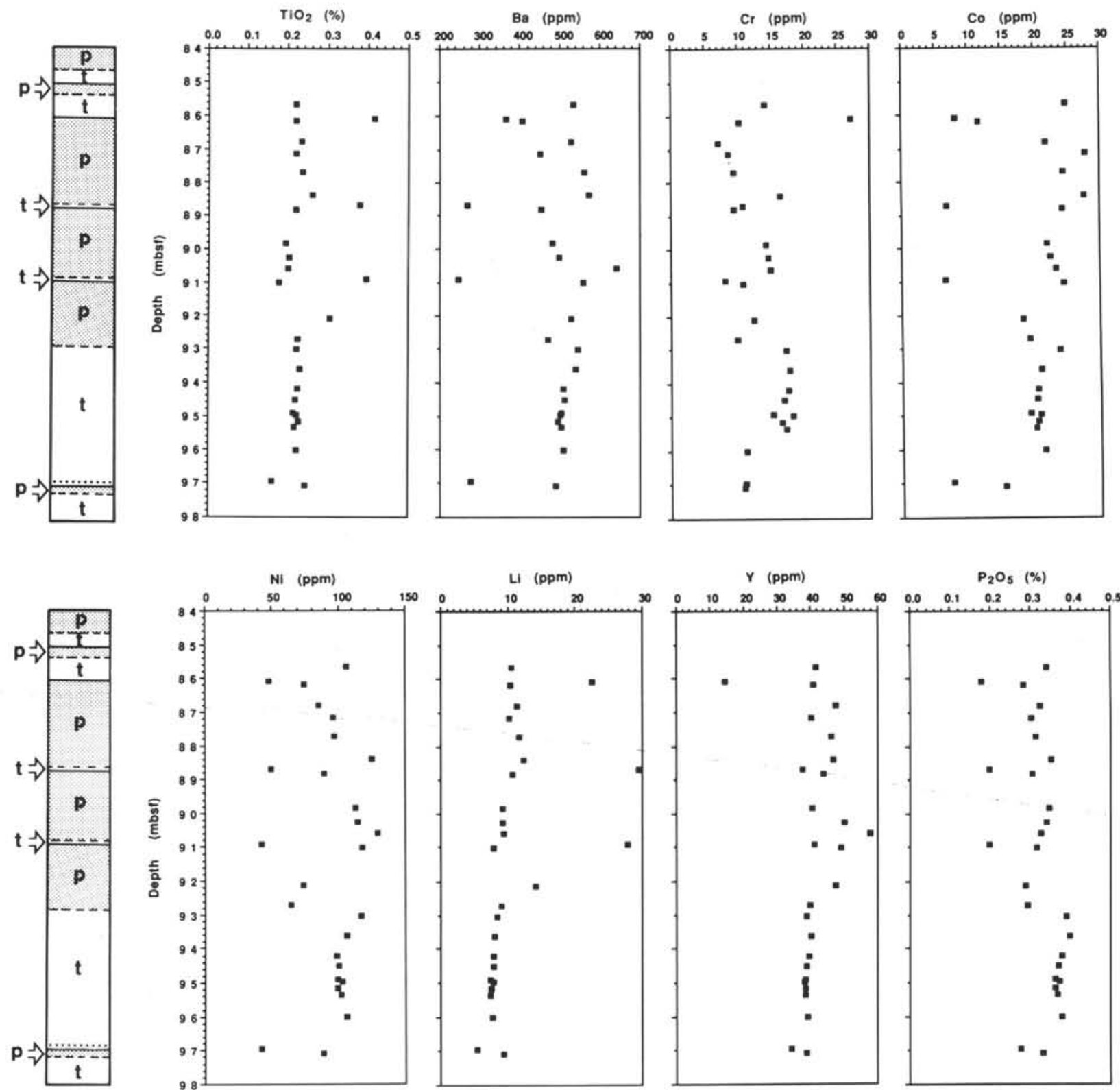

Figure 11. Graphic log through Sections 135-835A-9H-6 to -11H-2 (84-98 mbsf), showing a sequence of clayey nannofossil ooze hemipelagites (p) and turbidites $(t)$, with selected downcore geochemical profiles plotted alongside. Note the variability in the hemipelagic intervals compared to the turbidite muds, which show consistent values throughout.

Sedimentation at Site 835 over the last 3 m.y. has been dominated by redeposited sediments. These make up $75 \%$ of the total sediment thickness deposited during this time. In contrast, sedimentation at Site 834 during this period has been dominated by hemipelagic deposition, with redeposited sediments composing only $17 \%$ of the broadly time-equivalent sediment thickness. The average hemipelagic sedimentation rate at both sites is about $1.5 \mathrm{~cm} / \mathrm{k} \cdot \mathrm{y}^{-1}$.

Four main episodes of instability can be identified at Site 835 . These occurred from 0 to $0.4,0.9$ to $1.0,1.4$ to 1.7 , and 2.1 to $2.9 \mathrm{Ma}$ and involved catastrophic slope failures, with the emplacement of thick muddy debris flows that often carried large rafted blocks and thick mud turbidites. At Site 834, a marked increase in frequency of turbidite emplacement and the thickness and "sandiness" of the turbidites has occurred since $200 \mathrm{ka}$. Before this, until 2.3 Ma, deposition had been mainly hemipelagic.
Periods of instability resulting in turbidite emplacement at Site 834 appear to correlate broadly with the approach and passing of the East Lau and Central Lau propagators at around 3.6 and 0.5 to 0.6 $\mathrm{Ma}$, respectively. The most recent episode of instability at Site 835 , beginning around $0.4 \mathrm{Ma}$, appears to correlate with the approach and passing of the Central Lau propagator.

\section{ACKNOWLEDGMENTS}

We would like to thank Charlotte Gravestock for her help with sample preparation. We thank Kirsty Lyons for her help in drafting some of the figures. We also thank Chris MacLeod for his help in assessing the downhole geophysical logs. We are grateful to Chris Mato, John Miller, and the staff at the ODP Gulf Coast Repository, College Station, Texas, for their assistance in sampling the Leg 135 


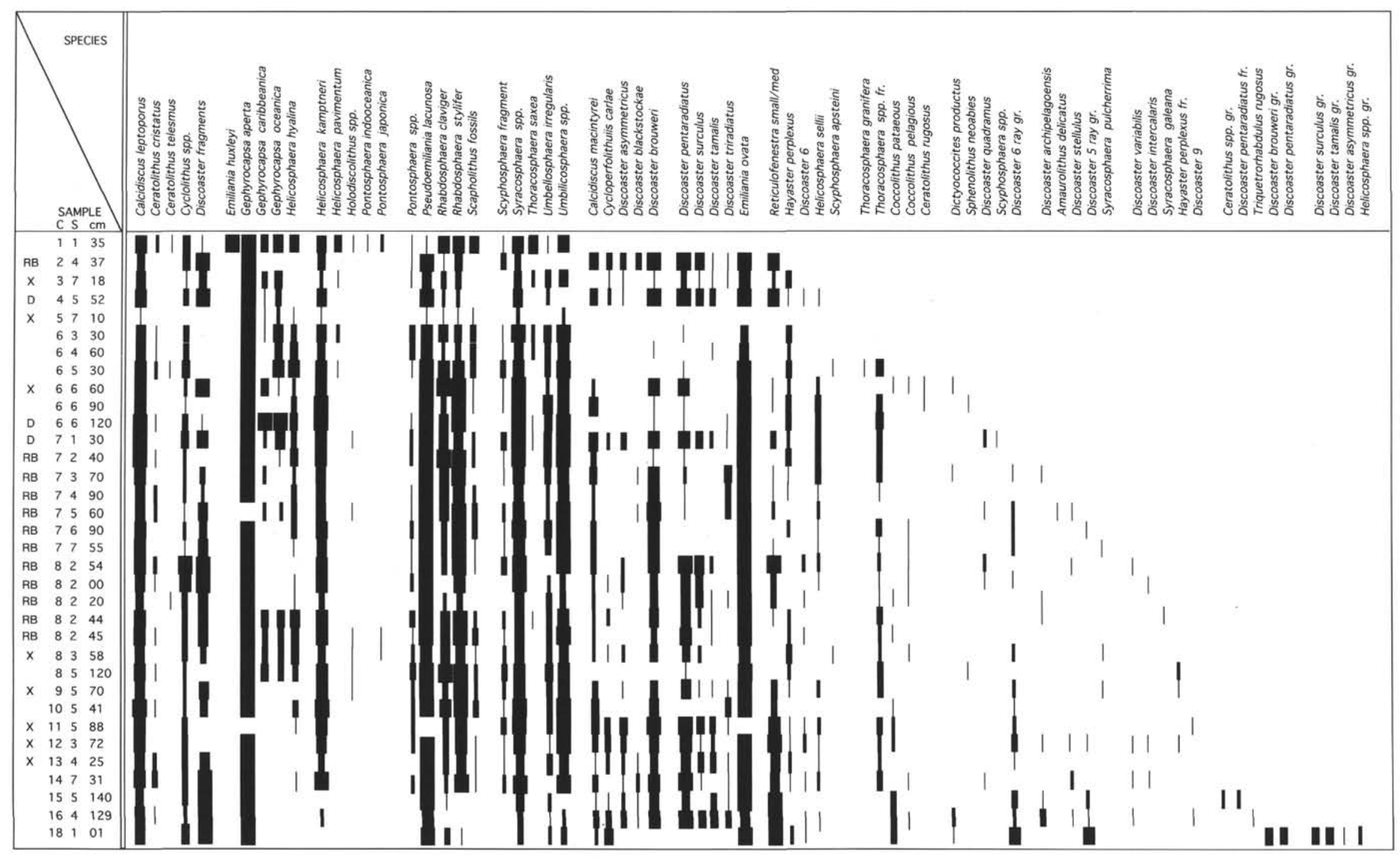

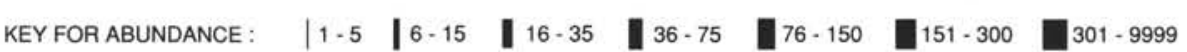

Figure 12. Distribution of calcareous nannofossils at Site 835 , including data from hemipelagic and reworked horizons. $\mathrm{X}=$ sample from turbidite, $\mathrm{D}=$ sample from debrite, and RB $=$ sample from rafted block. 


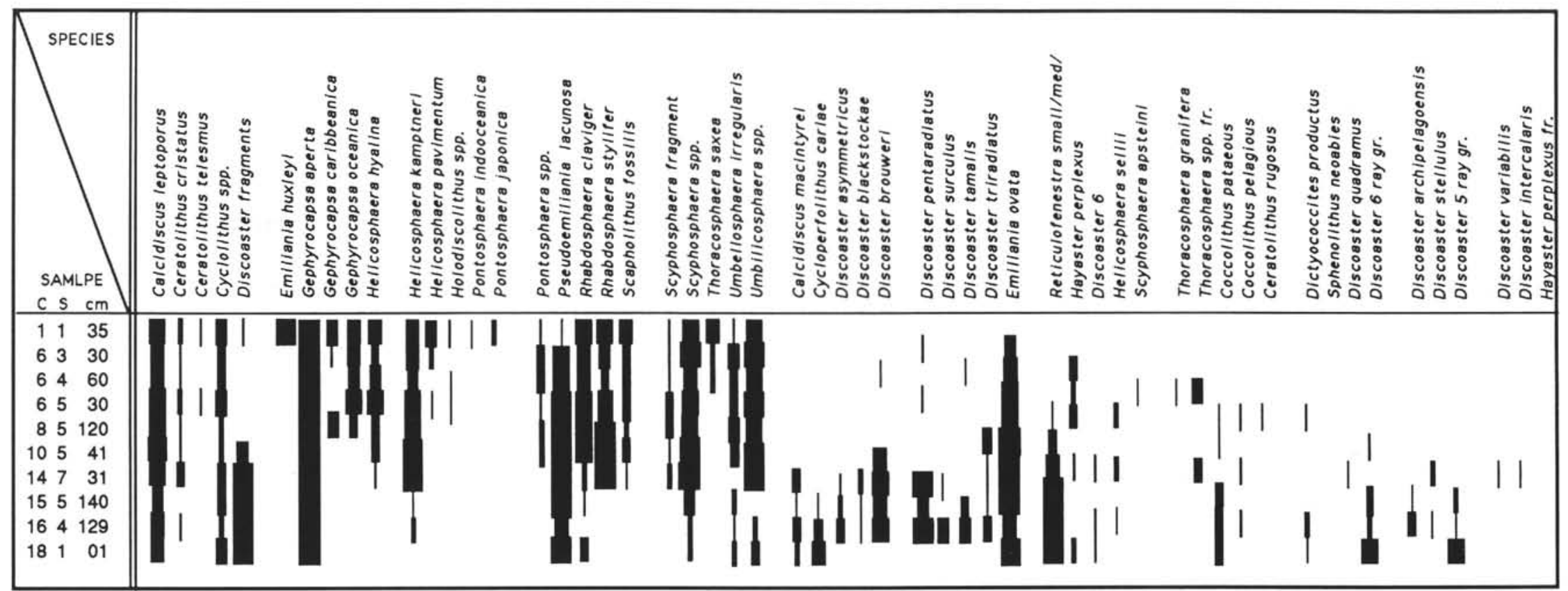

Figure 13. Distribution of calcareous nannofossils at Site 835. Data limited to samples from hemipelagic layers. 
sediment cores. We would also like to thank the shipboard scientific party, the ODP technicians, and the SEDCO drilling crew of Leg 135 during which the data were collected. The paper was improved by comments by Patrick Lineberger and Lionel Carter, who reviewed the paper. The paper also benefitted from discussion with Jim Andrews. Mike Conquer is thanked for producing the photographic prints.

\section{REFERENCES $*$}

Bouma, A.H., 1962. Sedimentology of Some Flysch Deposits: Amsterdam (Elsevier).

Brunner, C.A., and Ledbetter, M.T., 1987. Sedimentological and micropaleontological detection of turbidite muds in hemipelagic sequences: an example from the late Pleistocene levee of Monterey Fan, central California continental margin. Mar. Micropaleontol., 12:223-239.

Brunner, C.A., and Normark, W.R., 1985. Biostratigraphic implications for turbidite depositional processes on the Monterey Deep Sea Fan, central California. J. Sediment. Petrol., 55:495-505.

Einsele, G., and Kelts, K., 1982. Pliocene and Quaternary mud turbidites in the Gulf of California: sedimentology, mass physical properties and significance. In Curray, J.R., Moore, D.G., et al. Init. Repts. DSDP, 64: Washington (U.S. Govt. Printing Office), 511-528.

Folk, R.L., 1974. Petrology of Sedimentary Rocks: Austin (Hemphill Publ.).

Gill, J.B., 1976. Composition and age of Lau Basin and Ridge volcanic rocks: implications for evolution of an interarc basin and remanent arc. Geol. Soc. Am. Bull., 87:1384-1395.

Goddard, E.N., Trask, P.D., De Ford, R.K., Rove, O.N., Singewald, J.T., and Overbeck, R.M., 1979. Rock color chart. Geol. Soc. Am.

Hesse, R., 1975. Turbiditic and non-turbiditic mudstone of Cretaceous flysch sections of the East Alps and other basins. Sedimentology, 22:387-416.

Kelts, K., and Arthur, M.A., 1981. Turbidites after ten years of deep-sea drilling - wringing out the mop? In Warme, J.E., Douglas, R.G., and Winterer, E.L. (Eds.), The Deep Sea Drilling Project: A Decade of Progress. Spec. Publ.-Soc. Econ. Paleontol. Mineral., 32:91-127.

Klein, G. deV., 1985. The control of depositional depth, tectonic uplift and volcanism on sedimentation processes in the back-arc basins of the western Pacific Ocean. J. Geol., 93:1-25.

Kuenen, P.H., 1964. The shell pavement below oceanic turbidites. Mar. Geol., 2:236-246.

Pantin, H.M., and Leeder, M.R., 1987. Reverse flow in turbidity currents: the role of internal solitons. Sedimentology, 34:1143-1155.

Pickering, K.T., and Hiscott, R.N., 1985. Contained (reflected) turbidity currents from the Middle Ordovician Cloridorme Formation, Quebec, Canada: an alternative to the antidune hypothesis. Sedimentology, 32:373-394.

Pilkey, O.H., 1987. Sedimentology of basin plains. In Weaver, P.P.E., and Thompson, J. (Eds.), Geology and Geochemistry of Abyssal Plains. Geol. Soc. Spec. Publ. London, 31:1-12.

Piper, D.J.W., 1978. Turbidite muds and silts on deep sea fans and abyssal plains. In Stanley, D.J., and Kelling, G. (Eds.), Sedimentation in Subma- rine Canyons, Fans, and Trenches: Stroudsberg, PA(Dowden, Hutchinson and Ross), 163-176.

Porebski, S.J., Meischner, D., and Gorlich, K., 1991. Quaternary mud turbidites from the South Shetland Trench (West Antarctica): recognition and implications for turbidite facies modelling. Sedimentology, 38:691-715.

Reich, V., Marchig, V., Sunkel, G., and Weiss, W., 1990. Hydrothermal and volcanic input in sediments of the Lau Back-Arc Basin, S.W. Pacific. Mar. Mining, 9:183-203.

Rothwell, R.G., Pearce, T.J., and Weaver, P.P.E., 1992. Late Quaternary evolution of the Madeira Abyssal Plain, Canary Basin, NE Atlantic. Basin Res., 4:103-131.

Shipboard Scientific Party, 1987. Site 650: Marsili Basin. In Kastens, K.A., Mascle, J., Auroux, C., et al., Proc. ODP, Init. Repts., 107: College Station, TX (Ocean Drilling Program), 129-286.

, 1992a. Site 834. In Parson, L., Hawkins, J., Allan, J., et al., Proc. ODP, Init. Repts., 135: College Station, TX (Ocean Drilling Program), 85-180.

1992b. Site 835. In Parson, L., Hawkins, J., Allan, J., et al., Proc. ODP, Init. Repts., 135: College Station, TX (Ocean Drilling Program), 181-245.

Totland, M., Jarvis, I., and Jarvis, K.E., 1992. An assessment of dissolution techniques for the analysis of geological samples by plasma spectrometry. Chem. Geol., 95:35-62.

Van Andel, T.H., and Komar, P.D., 1969. Ponded sediments of the Mid-Atlantic Ridge between $22^{\circ}$ and $23^{\circ}$ North Latitude. Geol. Soc. Am. Bull., 80:11631190.

Van der Lingen, G.J., 1969. The turbidite problem. N.Z. J. Geol. Geophys., $12: 7-50$.

Weaver, P.P.E., and Kuijpers, A., 1983. Climatic control of turbidite deposition on the Madeira Abyssal Plain. Nature, 306:360-363.

Weaver, P.P.E., and Rothwell, R.G., 1987. Sedimentation on the Madiera Abyssal Plain over the last 300,000 years. In Weaver, P.P.E., and Thompson, J. (Eds.), Geology and Geochemistry of Abyssal Plains. Geol. Soc. Spec. Publ. London, 31:71-86.

Wetzel, A., 1986. Anisotropy and modes of deposition of pelitic Mississippi Fan deposits. In Bouma, A.H., Coleman, J.M., Meyer, A.W., et al., Init. Repts. DSDP, 96: Washington (U.S. Govt. Printing Office), 811-817.

Woodhall, D., 1985. Geology of the Lau Ridge. In Scholl, D., and Vallier, T.L. (Eds.), Geology and Offshore Resources of Pacific Island Arc-Tonga Region. Circum-Pac. Counc. Energy Miner. Resour., Earth Sci. Ser., 2:351-378.

Abbreviations for names of organizations and publication titles in ODP reference lists follow the style given in Chemical Abstracts Service Source Index (published by American Chemical Society).

Date of initial receipt: 2 July 1992

Date of acceptance: 5 January 1993

Ms 135SR-108 
Table 4. List of allochthonous and hemipelagic beds in Lithologic Unit I at Hole 834A.

\begin{tabular}{|c|c|c|c|c|}
\hline $\begin{array}{l}\text { Core, section, } \\
\text { interval }(\mathrm{cm})\end{array}$ & $\begin{array}{l}\text { Depth } \\
\text { (mbsf) }\end{array}$ & Sediment type & $\begin{array}{l}\text { Thickness } \\
\text { of bed (m) }\end{array}$ & $\begin{array}{l}\text { Cumulative hemipelagic } \\
\text { thickness (m), with } \\
\text { nannofossil zone }\end{array}$ \\
\hline \multicolumn{5}{|l|}{$135-834 \mathrm{~A}$} \\
\hline $1 \mathrm{H}-1,0-42$ & $0.0-0.42$ & Hemipelagite & 0.42 & 0.42 \\
\hline $1 \mathrm{H}-1,42-141$ & $0.42-1.41$ & Turbidite & 0.99 & \\
\hline $1 \mathrm{H}-1,141$, to $1 \mathrm{H}-2,26$ & $1.41-1.76$ & Turbidite & 0.35 & \\
\hline $1 \mathrm{H}-2,26-71$ & $1.76-2.21$ & Hemipelagite & 0.45 & 0.87 \\
\hline $1 \mathrm{H}-2.71-111$ & $2.21-2.61$ & Turbidite & 0.40 & \\
\hline $1 \mathrm{H}-2,111$, to $1 \mathrm{H}-3,56$ & $2.61-3.56$ & Hemipelagite & 0.95 & 1.82 \\
\hline $1 \mathrm{H}-3,56-69$ & $3.56-3.69$ & Turbidite & 0.13 & \\
\hline IH-3, 69, to $1 \mathrm{H}-4,20$ & $3.69-4.70$ & Hemipelagite & 1.01 & $2.83, \mathrm{NN} 19$ \\
\hline $1 \mathrm{H}-4,20$, to $1 \mathrm{H}-5,130$ & $4.70-7.30$ & Turbidite & 2.60 & \\
\hline $1 \mathrm{H}-5,130$, to $2 \mathrm{H}-1,95$ & $7.30-8.55$ & Turbidite & 1.25 & \\
\hline $2 \mathrm{H}-1,95$, to $2 \mathrm{H}-3,47$ & $8.55-11.07$ & Hemipelagite & 2.52 & $5.35, \mathrm{NN} 19$ \\
\hline $2 \mathrm{H}-3.47-49$ & $11.07-11.09$ & Tephra & 0.02 & \\
\hline $2 \mathrm{H}-3,49$, to $2 \mathrm{H}-4,35$ & $11.09-12.45$ & Hemipelagite & 1.36 & 6.71 \\
\hline $2 \mathrm{H}-4,35-46$ & $12.45-12.56$ & Turbidite & 0.11 & \\
\hline $2 \mathrm{H}-4,46-109$ & $12.56-13.19$ & Hemipelagite & 0.63 & 7.34 \\
\hline $2 \mathrm{H}-4,109-115$ & $13.19-13.25$ & Turbidite & 0.06 & \\
\hline $2 \mathrm{H}-4,115$, to $2 \mathrm{H}-6,20$ & $13.25-15.30$ & Hernipelagite & 2.05 & $9.39, \mathrm{NN} 19$ \\
\hline $2 \mathrm{H}-6,20-37$ & $15.30-15.47$ & Turbidite & 0.17 & \\
\hline $2 \mathrm{H}-6,37-40$ & $15.47-15.50$ & Hemipelagite & 0.03 & 9.42 \\
\hline $2 \mathrm{H}-6,40-47$ & $15.50-15.57$ & Turbidite & 0.07 & \\
\hline $2 \mathrm{H}-6,47$, to $3 \mathrm{H}-1,38$ & $15.57-17.48$ & Hemipelagite & 1.91 & 11.33, NN19 \\
\hline $3 \mathrm{H}-1,38-45$ & $17.48-17.55$ & Void & 0.07 & \\
\hline $3 \mathrm{H}-1,45$, to $3 \mathrm{H}-2,71$ & $17.55-19.31$ & Hemipelagite & 1.76 & $13.09, \mathrm{NN} 19$ \\
\hline $3 \mathrm{H}-2,71-73$ & $19.31-19.33$ & Turbidite & 0.02 & \\
\hline $3 \mathrm{H}-2,73-95$ & $19.33-19.55$ & Hemipelagite & 0.22 & 13.31 \\
\hline $3 \mathrm{H}-2,95-105$ & $19.55-19.65$ & Turbidite & 0.10 & \\
\hline $3 \mathrm{H}-2,105$, to $3 \mathrm{H}-4,90$ & $19.65-22.50$ & Hemipelagite & 2.85 & $16.16, \mathrm{NN} 19$ \\
\hline $3 \mathrm{H}-4,90-94$ & $22.50-22.54$ & Turbidite & 0.04 & \\
\hline $3 \mathrm{H}-4.94-131$ & $22.54-22.91$ & Hemipelagite & 0.37 & 16.53 \\
\hline $3 \mathrm{H}-4,131-136$ & $22.91-22.96$ & Turbidite & 0.05 & \\
\hline $3 \mathrm{H}-4,136$, to $3 \mathrm{H}-5,37$ & $22.96-23.37$ & Hemipelagite & 0.41 & 16.94 \\
\hline $3 \mathrm{H}-5,37-41$ & $23.37-23.41$ & Turbidite & 0.04 & \\
\hline $3 \mathrm{H}-5,41-90$ & $23.41-23.90$ & Hemipelagite & 0.49 & 17.43 \\
\hline $3 \mathrm{H}-5,90-96$ & $23.90-23.96$ & Turbidite & 0.06 & \\
\hline $3 \mathrm{H}-5,96$, to $4 \mathrm{H}-1,140$ & $23.96-28.00$ & Hemipelagite & 4.04 & $21.47, \mathrm{NN} 19$ \\
\hline $4 \mathrm{H}-1,140$, to $4 \mathrm{H}-2,52$ & $28.00-28.62$ & Turbidite & 0.62 & \\
\hline $4 \mathrm{H}-2,52$, to $4 \mathrm{H}-5,23$ & $28.62-32.68$ & Hemipelagite & 4.06 & 25.53, NN19 \\
\hline $4 \mathrm{H}-5,23-47$ & $32.68-32.92$ & Turbidite & 0.24 & \\
\hline $4 \mathrm{H}-5,47$, to $5 \mathrm{H}-5,73$ & $32.92-42.71$ & Hemipelagite & 9.79 & $35.32, \mathrm{NN} 18$ \\
\hline
\end{tabular}


Table 5. List of allochthonous and hemipelagic beds in Lithologic Unit I at Hole 835A.

\begin{tabular}{|c|c|c|c|c|}
\hline Core, section, interval (cm) & Depth (mbsf) & Sediment type & $\begin{array}{l}\text { Thickness } \\
\text { of bed (m) }\end{array}$ & $\begin{array}{l}\text { Cumulative hemipelagic } \\
\text { thickness (m), with } \\
\text { nannofossil zone }\end{array}$ \\
\hline \multicolumn{5}{|l|}{$135-835 \mathrm{~A}-$} \\
\hline $1 \mathrm{H}-1,0$ to $1 \mathrm{H}-2,21$ & $0-1.71$ & Hemipelagite & 1.71 & 1.71 \\
\hline $1 \mathrm{H}-2,21-57$ & $1.71-2.07$ & Turbidite & 0.36 & $-\overline{261}$ \\
\hline $1 \mathrm{H}-2,57-150$ & $2.07-3.00$ & Hemipelagite & 0.93 & 2.64 \\
\hline $1 \mathrm{H}-3,0-69$ & $3.00-3.69$ & Turbidite & 0.69 & - \\
\hline $1 \mathrm{H}-3,69$, to $1 \mathrm{H}-6,98$ & $3.69-8.38$ & Turbidite & 4.69 & 一 \\
\hline $1 \mathrm{H}-6,98$, to $2 \mathrm{H}-1,115$ & $8.38-10.65$ & Debrite & 2.27 & - \\
\hline $2 \mathrm{H}-1,115$, to $2 \mathrm{H}-2,150$ & $10.65-12.50$ & Rafted block & 1.85 & - \\
\hline $2 \mathrm{H}-3,0-150$ & $12.50-14.00$ & Debrite & 1.50 & 一 \\
\hline $2 \mathrm{H}-4,0-110$ & $14.00-15.10$ & Rafted block & 1.10 & 一 \\
\hline $2 \mathrm{H}-4,110$, to $2 \mathrm{H}-\mathrm{CC}, 18$ & $15.10-19.00$ & Debrite & 3.90 & - \\
\hline $3 \mathrm{H}-1,0-140$ & $19.00-20.40$ & Rafted block & 1.40 & 一 \\
\hline $3 \mathrm{H}-1,140$, to $3 \mathrm{H}-2,29$ & $20.40-20.79$ & Turbidite & 0.39 & - \\
\hline $3 \mathrm{H}-2,29-109$ & $20.79-21.59$ & Turbidite & 0.80 & 一 \\
\hline $3 \mathrm{H}-2,109$, to $3 \mathrm{H}-3,7$ & $21.59-22.07$ & Turbidite & 0.48 & - \\
\hline $3 \mathrm{H}-3,7-40$ & $22.07-22.40$ & Turbidite & 0.33 & - \\
\hline $3 \mathrm{H}-3,40$, to $4 \mathrm{H}-2,15$ & $22.40-30.15$ & Turbidite & 7.75 & - \\
\hline $4 \mathrm{H}-2,15$, to $4 \mathrm{H}-6,5$ & $30.15-36.05$ & Debrite & 5.90 & - \\
\hline $4 \mathrm{H}-6,5-110$ & $36.05-37.15$ & Hemipelagite & 1.05 & 3.69 \\
\hline $4 \mathrm{H}-6,110-136$ & $37.15-37.41$ & Turbidite & 0.26 & - \\
\hline $4 \mathrm{H}-6,136$, to $4 \mathrm{H}-7,8$ & $37.41-37.63$ & Turbidite & 0.22 & - \\
\hline $4 \mathrm{H}-7,8-18$ & $37.63-37.73$ & Turbidite & 0.10 & - \\
\hline $4 \mathrm{H}-7,18-22$ & $37.73-37.77$ & Turbidite & 0.04 & 一 \\
\hline $4 \mathrm{H}-7,22-31$ & $37.77-37.86$ & Turbidite & 0.09 & 一 \\
\hline $4 \mathrm{H}-7,31$, to $5 \mathrm{H}-1,139$ & $37.86-39.39$ & Turbidite & 1.53 & 一 \\
\hline $5 \mathrm{H}-1,139$, to $5 \mathrm{H}-2,92$ & $39.39-40.42$ & Debrite & 1.03 & 一 \\
\hline $5 \mathrm{H}-2,92$, to $5 \mathrm{H}-3,3$ & $40.42-41.03$ & Turbidite & 0.61 & - \\
\hline $5 \mathrm{H}-3,3-23$ & $41.03-41.23$ & Hemipelagite & 0.20 & $3.89, \mathrm{NN} 20$ \\
\hline $5 \mathrm{H}-3,23-49$ & $41.23-41.49$ & Turbidite & 0.26 & - \\
\hline $5 \mathrm{H}-3,49-65$ & $41.49-41.65$ & Hemipelagite & 0.16 & $4.05, \mathrm{NN} 20$ \\
\hline $5 \mathrm{H}-3,65-118$ & $41.65-42.18$ & Turbidite & 0.53 & - \\
\hline $5 \mathrm{H}-3,118-125$ & $42.18-42.25$ & Turbidite & 0.07 & $-\overline{-}$ \\
\hline $5 \mathrm{H}-3,125-142$ & $42.25-42.42$ & Hemipelagite & 0.17 & 4.22, NN20 \\
\hline $5 \mathrm{H}-3,142-148$ & $42.42-42.48$ & Tephra & 0.06 & - \\
\hline $5 \mathrm{H}-3,148$, to $5 \mathrm{H}-4,84$ & $42.48-43.34$ & Hemipelagite & 0.86 & $5.08, \mathrm{NN} 20$ \\
\hline $5 \mathrm{H}-4,84-91$ & $43.34-43.41$ & Turbidite & 0.07 & - \\
\hline $5 \mathrm{H}-4,91-100$ & $43.41-43.50$ & Turbidite & 0.09 & - \\
\hline $5 \mathrm{H}-4,100-117$ & $43.50-43.67$ & Hemipelagite & 0.17 & $5.25, \mathrm{NN} 20$ \\
\hline $5 \mathrm{H}-4,117$, to $5 \mathrm{H}-6,23$ & $43.67-45.73$ & Turbidite & 2.06 & - \\
\hline $5 \mathrm{H}-6,23-69$ & $45.73-46.19$ & Hemipelagite & 0.46 & $5.71, \mathrm{NN} 20$ \\
\hline $5 \mathrm{H}-6,69-79$ & $46.19-46.29$ & Tephra & 0.10 & - \\
\hline $5 \mathrm{H}-6,79-148$ & $46.29-46.98$ & Hemipelagite & 0.69 & $6.40, \mathrm{NN} 20$ \\
\hline $5 \mathrm{H}-6,148$, to $5 \mathrm{H}-7,21$ & $46.98-47.21$ & Turbidite & 0.23 & - \\
\hline $5 \mathrm{H}-7,21$, to $6 \mathrm{H}-1,122$ & $47.21-48.72$ & Hemipelagite & 1.51 & 7.91, NN19 \\
\hline $6 \mathrm{H}-1,122$, to $6 \mathrm{H}-2,59$ & $48.72-49.59$ & Turbidite & 0.87 & - \\
\hline $6 \mathrm{H}-2,59$, to $6 \mathrm{H}-3,122$ & $49.59-51.72$ & Hemipelagite & 2.13 & $10.04, \mathrm{NN} 19$ \\
\hline $6 \mathrm{H}-3,122-125$ & $51.72-51.75$ & Tephra & 0.03 & - \\
\hline $6 \mathrm{H}-3,125$, to $6 \mathrm{H}-4,71$ & $51.75-52.71$ & Hemipelagite & 0.96 & $11.00, \mathrm{NN} 19$ \\
\hline $6 \mathrm{H}-4,71-75$ & $52.71-52.75$ & Tephra & 0.04 & - \\
\hline $6 \mathrm{H}-4,75$, to $6 \mathrm{H}-6,65$ & $52.75-55.50$ & Hemipelagite & 2.75 & $13.75, \mathrm{NN} 19$ \\
\hline $6 \mathrm{H}-6,65$, to $7 \mathrm{H}-1,105$ & $55.50-58.05$ & Debrite & 2.55 & - \\
\hline $7 \mathrm{H}-1,105$, to $8 \mathrm{H}-2,141$ & $58.05-69.41$ & Rafted block & 11.36 & 一 \\
\hline $8 \mathrm{H}-2,141$, to $8 \mathrm{H}-4,42$ & $69.41-71.42$ & Turbidite & 2.01 & - \\
\hline $8 \mathrm{H}-4,42$, to $9 \mathrm{H}-1,14$ & $71.42-76.14$ & Hemipelagite & 4.72 & $18.47, \mathrm{NN} 19$ \\
\hline $9 \mathrm{H}-1,14-30$ & $76.14-76.30$ & Layer of pumice & 0.16 & - \\
\hline $9 \mathrm{H}-1,30$, to $9 \mathrm{H}-2,19$ & $76.30-77.69$ & Hemipelagite & 1.39 & $19.86, \mathrm{NN} 19$ \\
\hline $9 \mathrm{H}-2,19-51$ & $77.69-78.01$ & Turbidite & 0.32 & - \\
\hline $9 \mathrm{H}-2,51$, to $9 \mathrm{H}-3,54$ & $78.01-79.54$ & Turbidite & 1.53 & - \\
\hline $9 \mathrm{H}-3,54-95$ & $79.54-79.95$ & Hemipelagite & 0.41 & 20.27, NN19 \\
\hline $9 \mathrm{H}-3,95-125$ & $79.95-80.25$ & Turbidite & 0.30 & - \\
\hline $9 \mathrm{H}-3,125$, to $9 \mathrm{H}-4,69$ & $80.25-81.19$ & Hemipelagite & 0.94 & $21.21, \mathrm{NN} 19$ \\
\hline $9 \mathrm{H}-4,69-81$ & $81.19-81.31$ & Turbidite & 0.12 & - \\
\hline $9 \mathrm{H}-4,81-114$ & $81.31-81.64$ & Hemipelagite & 0.33 & $21.54, \mathrm{NN} 19$ \\
\hline $9 \mathrm{H}-4,114-122$ & $81.64-81.72$ & Turbidite & 0.08 & - \\
\hline $9 \mathrm{H}-4,122-145$ & $81.72-81.95$ & Hemipelagite & 0.23 & 21.77, NN19 \\
\hline $9 \mathrm{H}-4,145$, to $9 \mathrm{H}-6,2$ & $81.95-83.52$ & Turbidite & 1.57 & - \\
\hline $9 \mathrm{H}-6,2,109 \mathrm{H}-7,11$ & $83.52-85.11$ & Hemipelagite & 1.59 & 23.36, NN19 \\
\hline $9 \mathrm{H}-7,11-52$ & $85.11-85.51$ & Turbidite & 0.41 & - \\
\hline $9 \mathrm{H}-7,52$, to $9 \mathrm{H}-\mathrm{CC}, 12$ & $85.51-85.80$ & Hemipelagite & 0.29 & 23.65 \\
\hline $9 \mathrm{H}-\mathrm{CC}, 12$, to $1 \mathrm{OH}-1,63$ & $85.80-86.13$ & Turbidite & 0.33 & - \\
\hline $10 \mathrm{H}-1,63$, to $1 \mathrm{OH}-2,135$ & $86.13-88.35$ & Hemipelagite & 2.22 & 25.87 \\
\hline $10 \mathrm{H}-2,135-137$ & $88.35-88.37$ & Turbidite & 0.02 & - \\
\hline $10 \mathrm{H}-2,137$, to $1 \mathrm{OH}-3,20$ & $88.37-88.70$ & Hemipelagite & 0.33 & 26.20 \\
\hline $10 \mathrm{H}-3,20-25$ & $88.70-88.75$ & Turbidite & 0.05 & - \\
\hline $10 \mathrm{H}-3,25$, to $10 \mathrm{H}-4,88$ & $88.75-90.88$ & Hemipelagite & 2.13 & 28.33 \\
\hline $10 \mathrm{H}-4,88-100$ & $90.88-91.00$ & Turbidite & 0.12 & $\overline{2025}$ \\
\hline $10 \mathrm{H}-4,100$, to $1 \mathrm{OH}-6,7$ & $91.00-92.92$ & Hemipelagite & 1.92 & 30.25 \\
\hline $10 \mathrm{H}-6,7$, to $11 \mathrm{H}-2,50$ & $92.92-97.00$ & Turbidite & 4.08 & - \\
\hline $11 \mathrm{H}-2,50-62$ & $97.00-97.12$ & Hemipelagite & 0.12 & 30.37 \\
\hline $11 \mathrm{H}-2,62$, to $13 \mathrm{H}-5,145$ & $97.12-121.45$ & Turbidite & 24.33 & - \\
\hline $13 \mathrm{H}-5,145$, to $14 \mathrm{H}-4,25$ & $121.45-128.22$ & Debrite & 6.77 & - \\
\hline $14 \mathrm{H}-4,25$, to $14 \mathrm{H}-5,62$ & $128.22-129.97$ & Turbidite & 1.75 & - \\
\hline
\end{tabular}


Age (Ma)

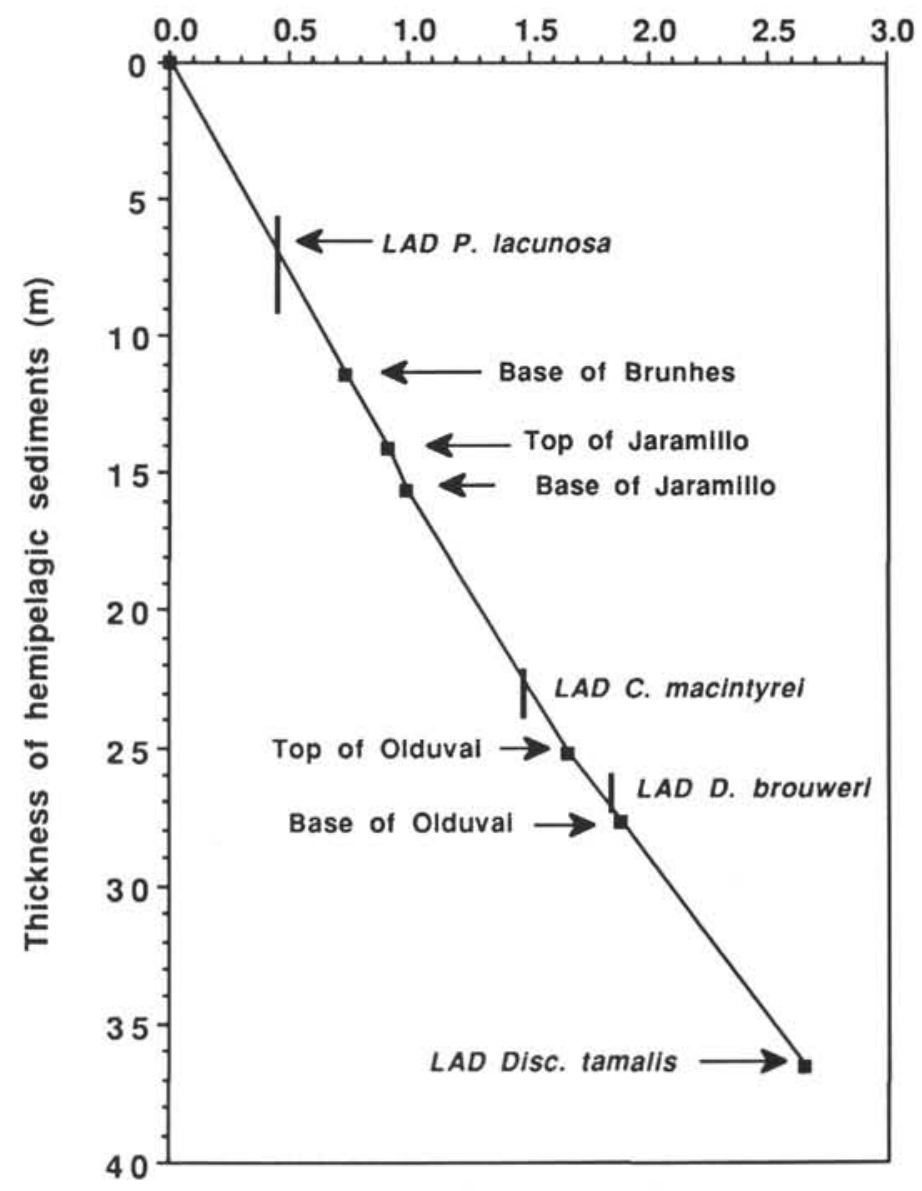

Figure 14. Sedimentation rate curve for hemipelagic sediments at Site 834 . Curve derived by subtracting redeposited beds from the sediment sequence and summing the remaining hemipelagic intervals and plotting thickness vs. occurrence of biostratigraphic and paleomagnetic datums that appear within hemipelagic intervals. Curve shows an average hemipelagic sedimentation rate of $1.46 \mathrm{~cm} / \mathrm{k} \cdot \mathrm{y}^{-1}$ for Site 834 .

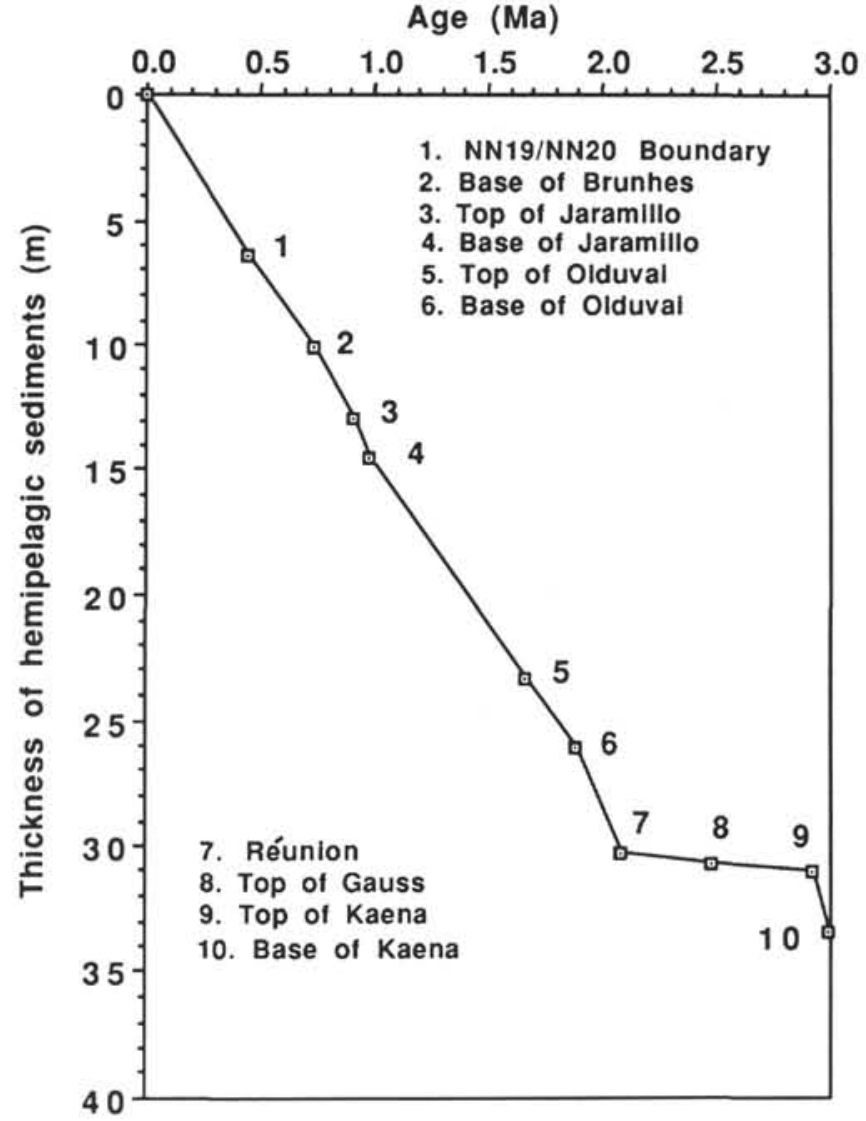

Figure 15. Sedimentation rate curve for hemipelagic sediments at Site 835 . Curve derived by subtracting redeposited beds from the sediment sequence and summing the remaining hemipelagic intervals and plotting thickness vs. occurrence of biostratigraphic and paleomagnetic datums that appear within hemipelagic intervals. Curve shows an average hemipelagic sedimentation rate of $1.44 \mathrm{~cm} / \mathrm{k} . \mathrm{y}^{-1}$ for Site 835 . Note the prominent hiatus evident between 2.1 and $2.9 \mathrm{Ma}$. 


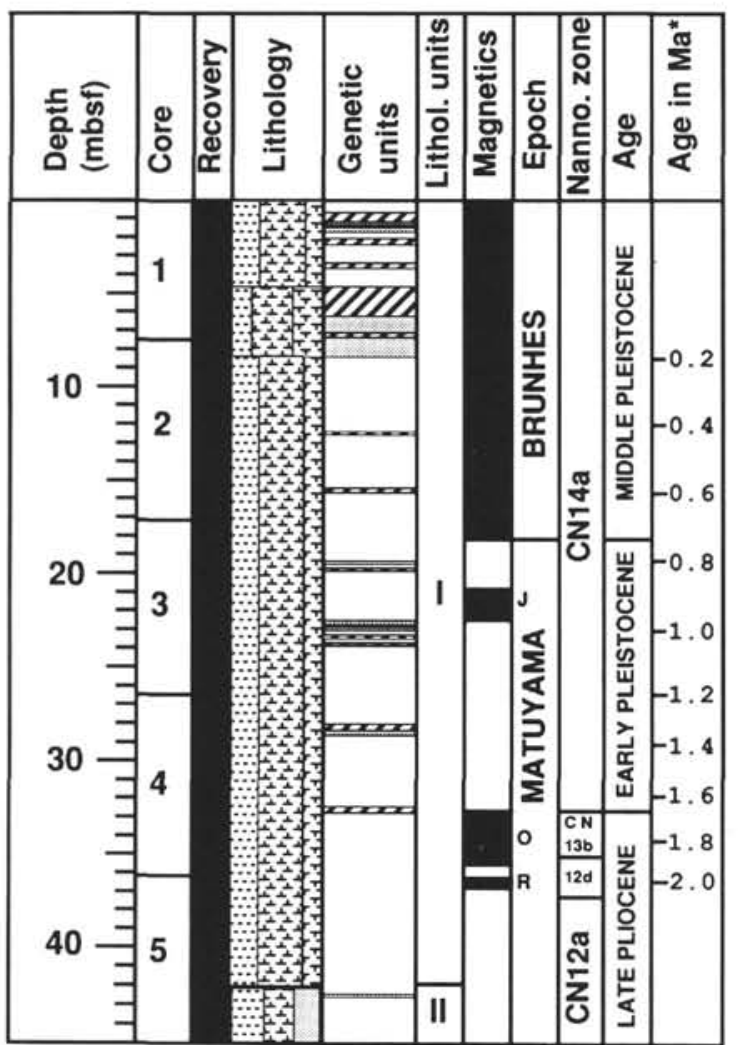

Key : (i) Lithology

(ii) Genetic units
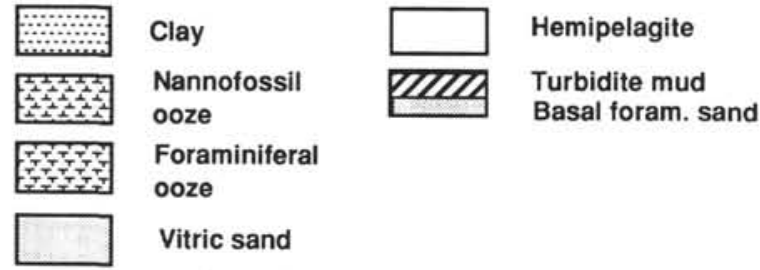

Figure 16. Genetic log through the upper Pliocene-Pleistocene sequence at Site 834 showing the occurrence of clayey nannofossil ooze hemipelagites and turbidites in the sequence, with magnetostratigraphic and biostratigraphic logs alongside. ${ }^{*}=$ Estimation of age in Ma was made primarily from calculations using the average hemipelagic sedimentation rate $\left(1.5 \mathrm{~cm} / \mathrm{k} \cdot \mathrm{y}^{-1}\right)$ constrained by shipboard paleomagnetic dating.

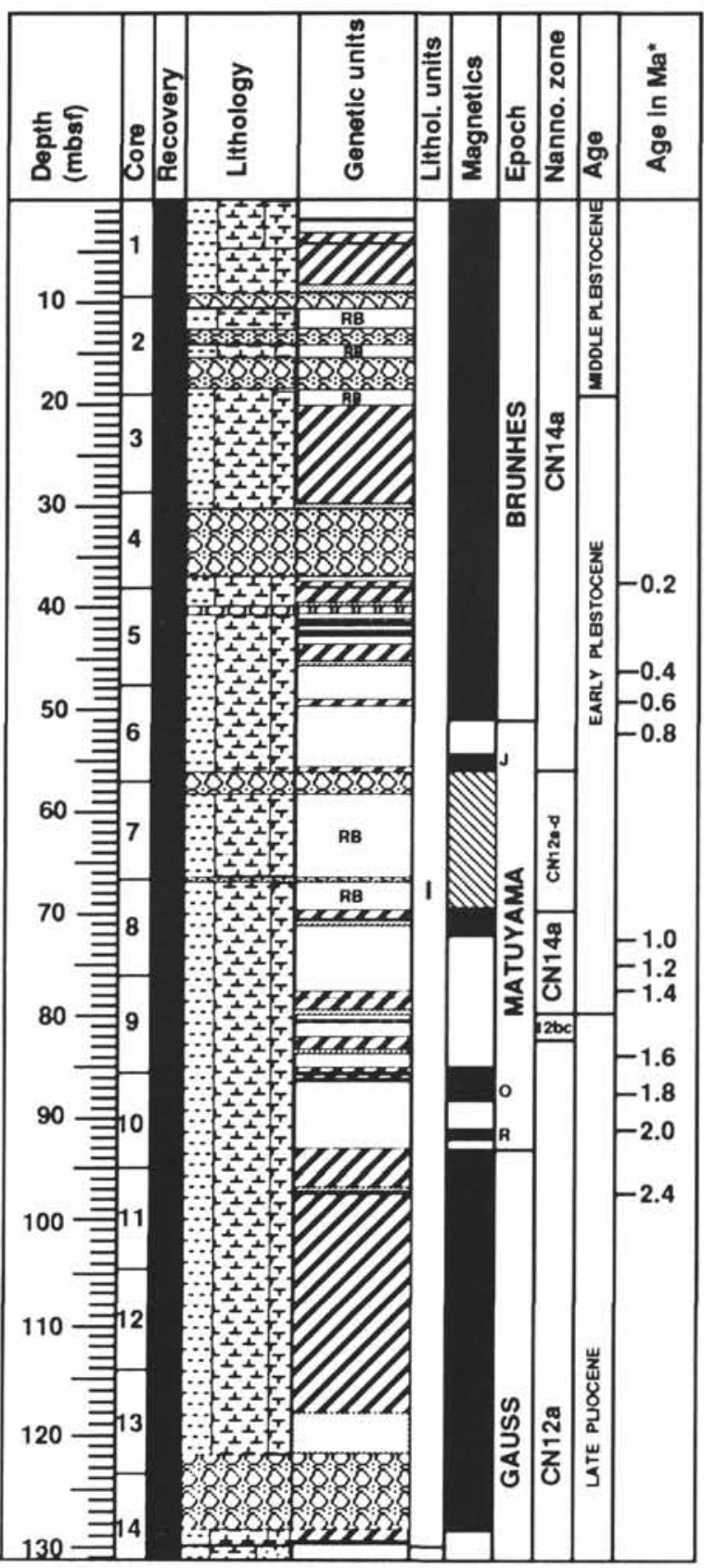

Key :
1) Lithology

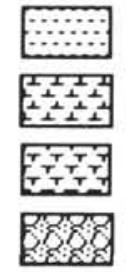

conglomerate

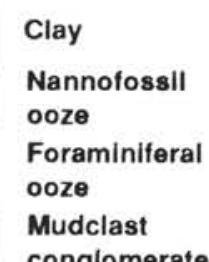

II) Genetic units

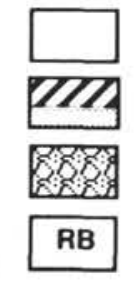

Hemipelagite

Turbidite mud Basal foram. sand

Debrite

Rafted block
Figure 17. Genetic log through the upper Pliocene-Pleistocene sequence at Site 835 showing the occurrence of debrites, turbidites, hemipelagites, and rafted blocks (identified from micropaleontologic evidence) in the sequence, with magnetostratigraphic and biostratigraphic logs alongside. ${ }^{*}=$ Estimation of age in Ma was made primarily from calculations using the average hemipelagic sedimentation rate $\left(1.5 \mathrm{~cm} / \mathrm{k} . \mathrm{y}^{-1}\right)$ constrained by shipboard paleomagnetic dating, 


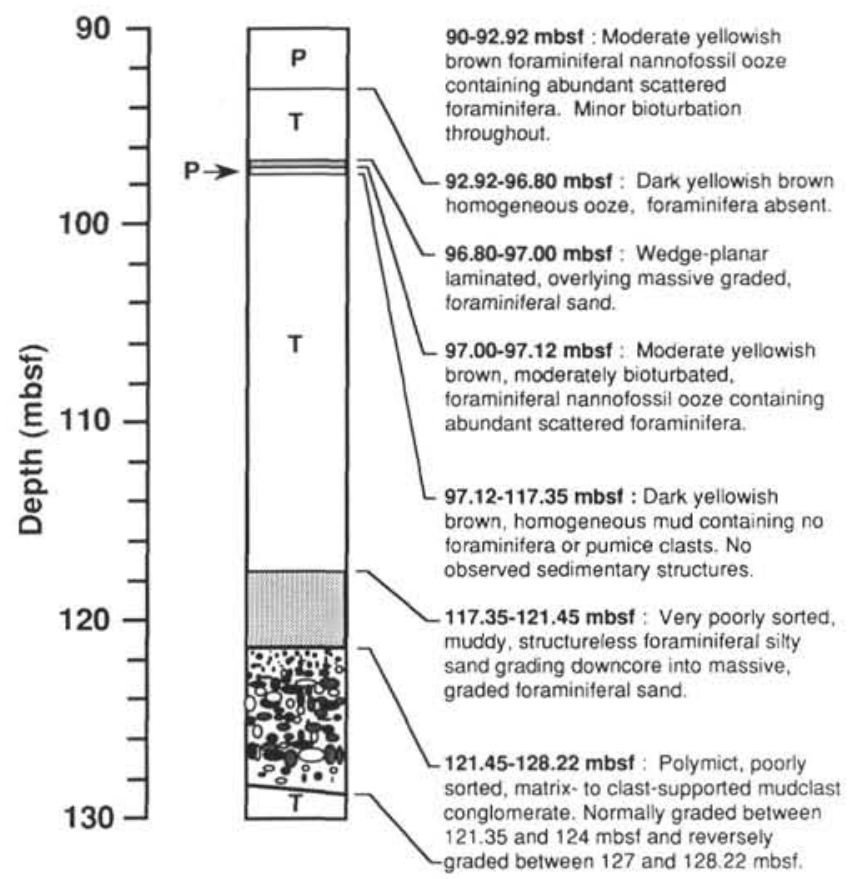

Key:

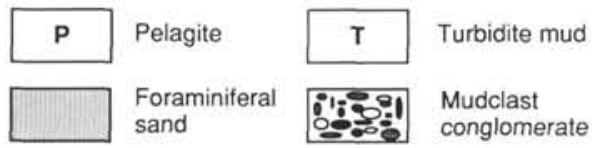

Figure 18. Genetic log through Sections $135-835 \mathrm{~A}-10 \mathrm{H}-4$ to $-14 \mathrm{H}-4$ (90-130 mbsf) showing very thick clayey nannofossil ooze turbidite mud overlying graded basal foraminiferal sand, directly overlying a muddy debris-flow deposit. This represents a slide complex emplaced about $2.5 \mathrm{Ma}$. 


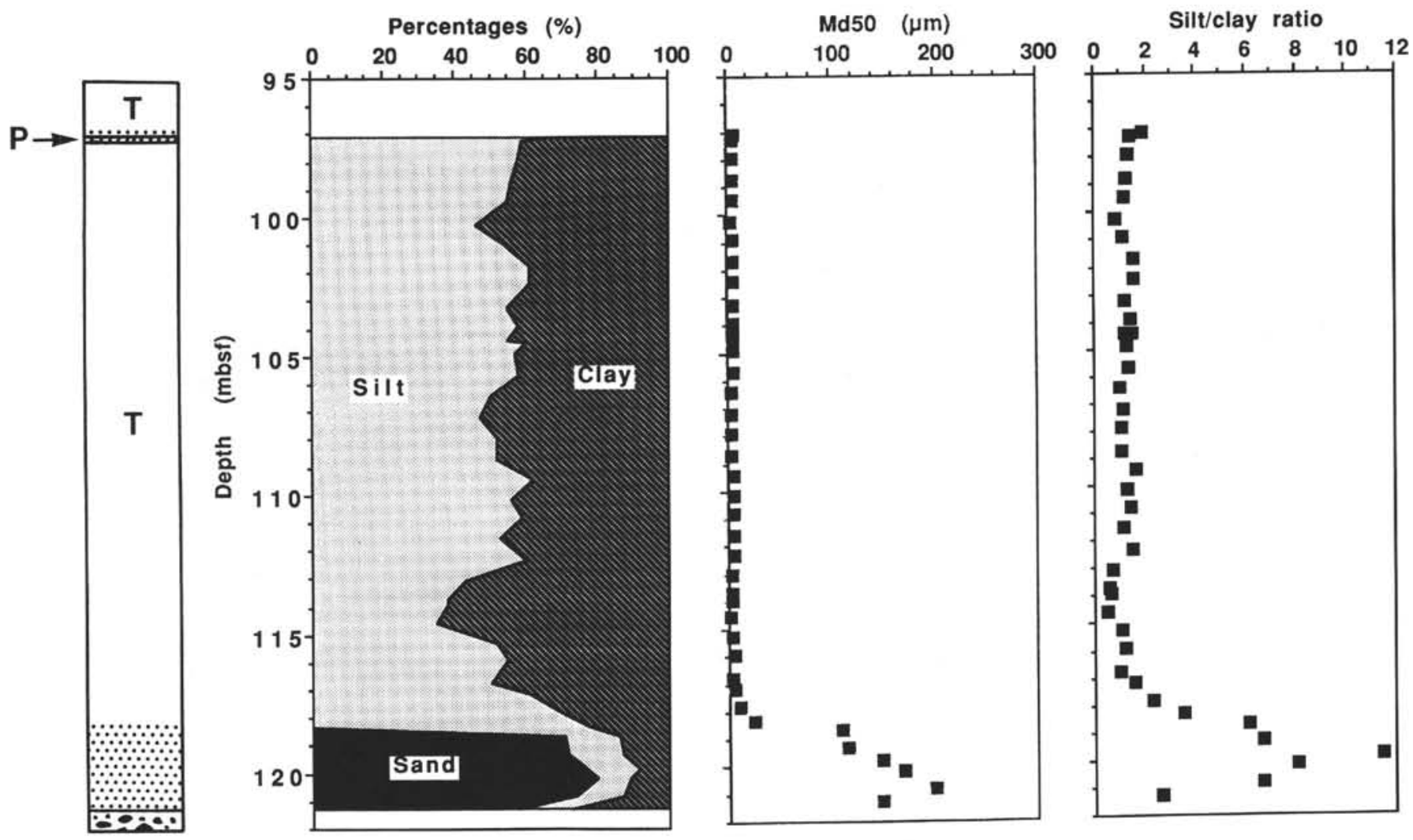

Figure 19. Grain-size profiles (sand/silt/clay percentage, median grain size, and silt/clay ratio) through the thick turbidite identified between 97.12 and 121.45 mbsf. Variability in the silt/clay content in the $T e$ mud division above the basal sand is interpreted as the effect of reflected flow from the flanks of the basin and backwash immediately following emplacement of the relatively large-volume flow in the restricted basin. Reversed grading at the base of the basal sand reflects incorporation of finer grained material from the underlying muddy debris-flow deposit. 


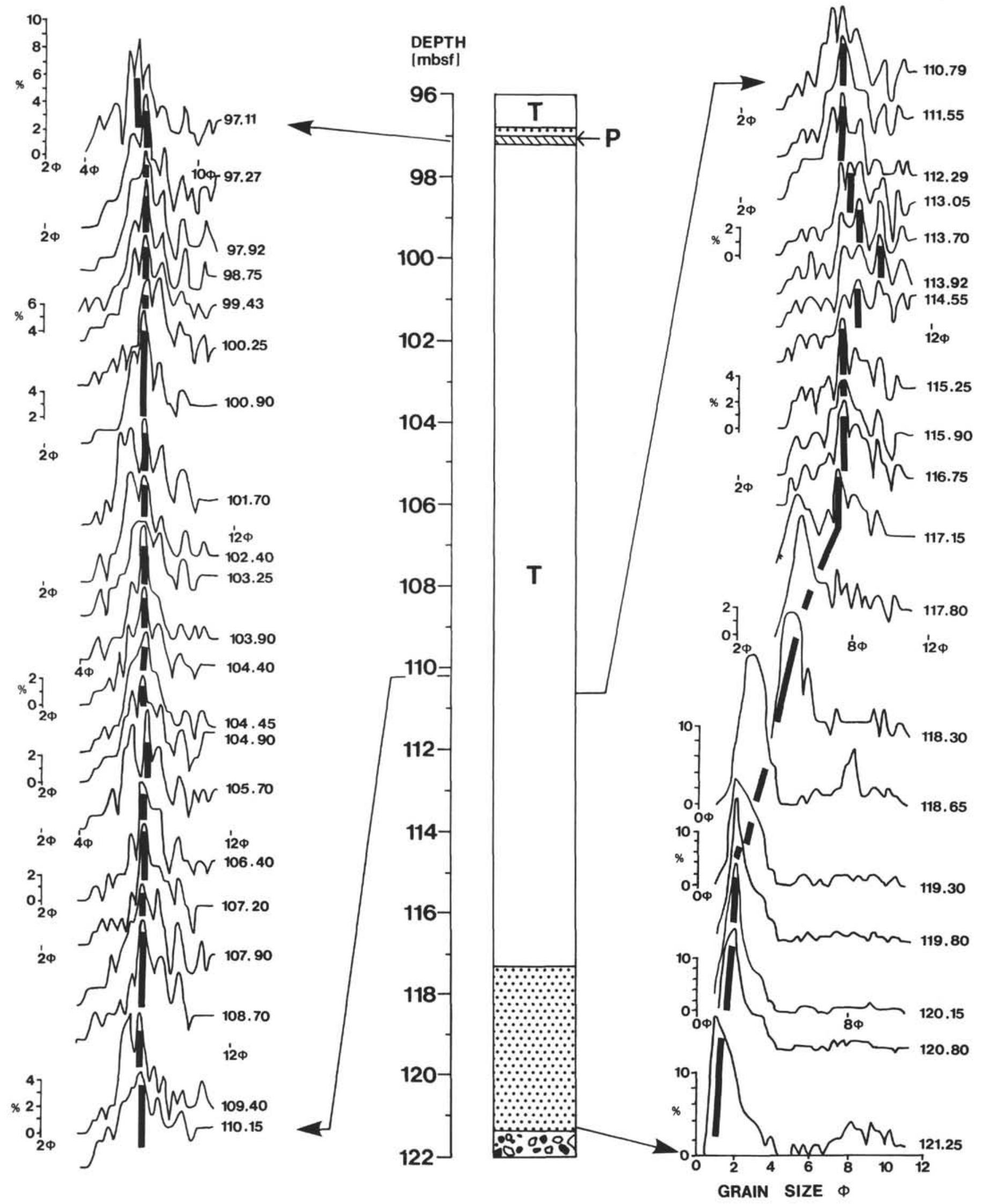

Figure 20. Stacked grain-size spectra through Sections 135-835A-11H-1 through to -13H-6 (96-122 mbsf). Note that the turbidite mud has a remarkably constant primary mode of around $7.5 \phi(5.5 \mu \mathrm{m})$ over a vertical thickness of $20 \mathrm{~m}$, although a brief shift to a finer primary mode occurs for a short interval between 113 and $115 \mathrm{mbsf}$. This may be an effect of flow reflection following containment of the flow within the basin. Within the mud, sand/coarse silt modes are rare or absent, although below 117 mbsf, the sediment grades into foraminiferal sand. 
A

Mn (\%)

01234567889101112

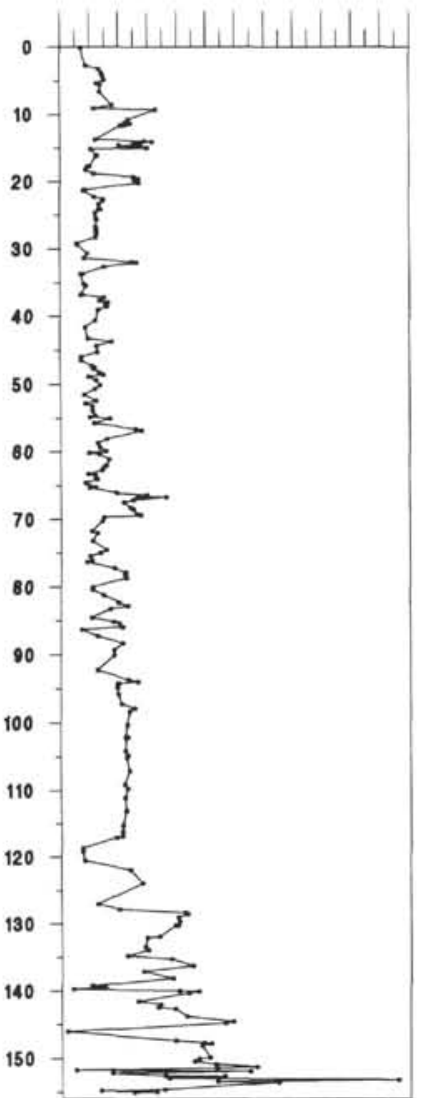

B

0

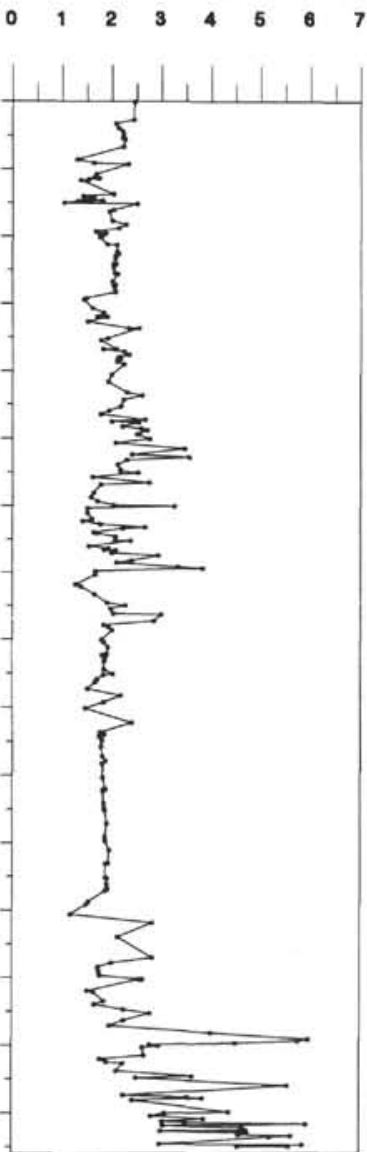

C

Co (ppm) $\begin{array}{lllll}30 & 30 \quad 40 \quad 50 \quad 60\end{array}$

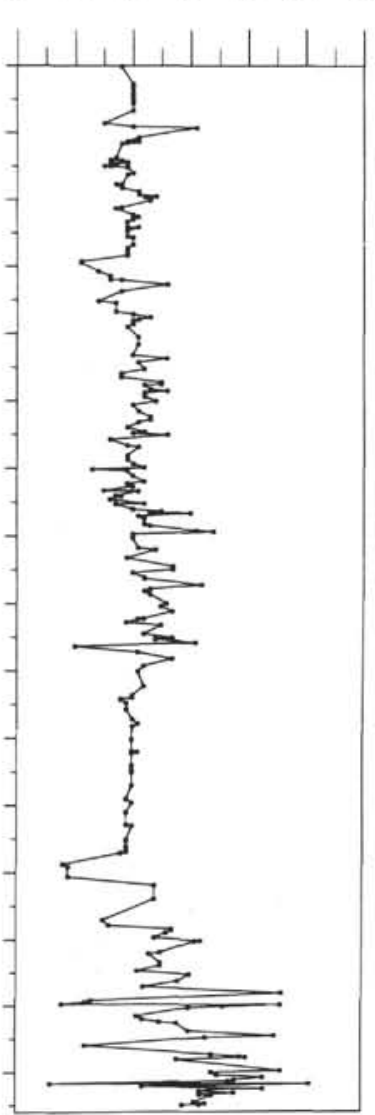

D

Ti (ppm)

$0 \quad 1000 \quad 2000 \quad 3000 \quad 4000$

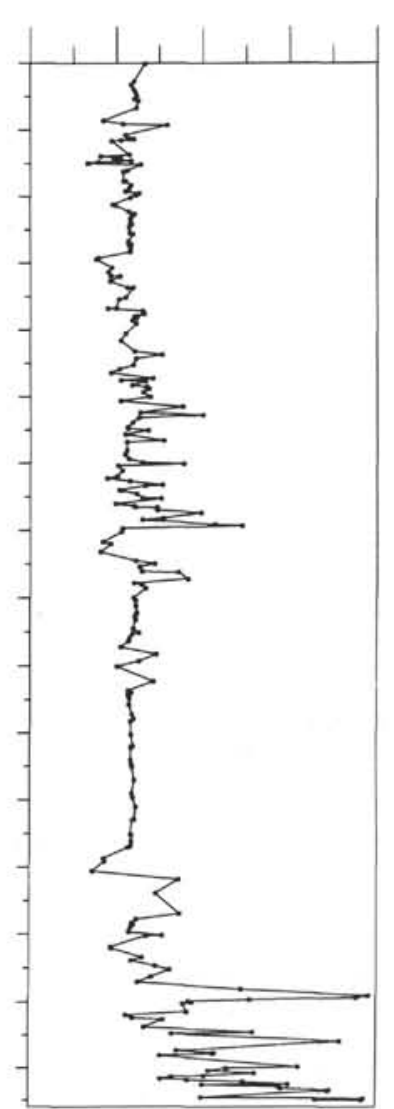

Figure 21. Selected downhole geochemical profiles for Site 835. A. Bulk Mn. B. Bulk Al. C. Bulk Co. D. Bulk Ti. Mn is a largely hydrothermally derived major element, and Co is a largely hydrothermally derived minor element. AI and Ti are major and minor elements, respectively, typically associated with detrital material. Note the remarkably constant values (shown by all elements, in addition to those illustrated here) in the interval from 97 to 117 mbsf, a characteristic of turbidites (see Figs. 10 and 11). 


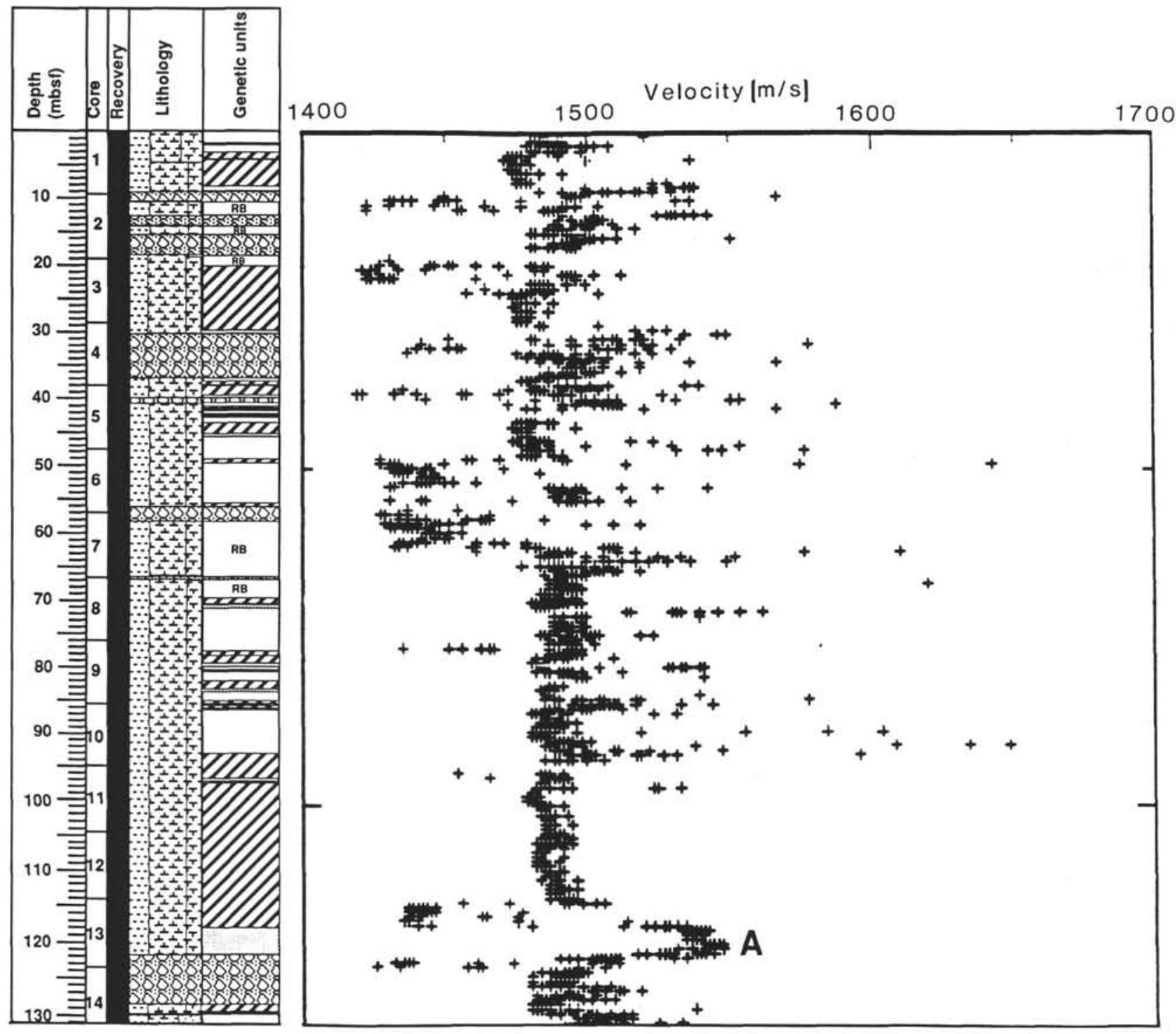

i) Lithology

ii) Genetic units

\begin{tabular}{|c|c|c|c|}
\hline & Clay & & Hemipelagite \\
\hline & $\begin{array}{l}\text { Nannofossil } \\
\text { ooze }\end{array}$ & ZD & $\begin{array}{l}\text { Turbidite mud } \\
\text { Basal foram. sand }\end{array}$ \\
\hline & $\begin{array}{l}\text { Foraminiferal } \\
\text { ooze }\end{array}$ & Bris: & Debrite \\
\hline $\begin{array}{l}\text { Fis: } \\
38 ;\end{array}$ & $\begin{array}{l}\text { Mudclast } \\
\text { conglomerate }\end{array}$ & RB & Rafted block \\
\hline
\end{tabular}

Figure 22. Downhole compressional velocity log, as measured by the $P$-wave logger, through Lithologic Unit I at Site 835 , with genetic log alongside. Note the prominent peak of increased velocity between 117 and $122 \mathrm{mbsf}(\mathrm{A})$. This appears to correlate with the thick foraminiferal sand at the base of a thick clayey nannofossil ooze turbidite. Note, too, that velocities are relatively constant through the interval from 97 to $117 \mathrm{mbsf}$, compared to those obtained through the rest of the hole. The total $P$-wave record through the interval from 97 to 122 mbsf is strongly reminiscent of that obtained through turbidite muds with sandy bases. 


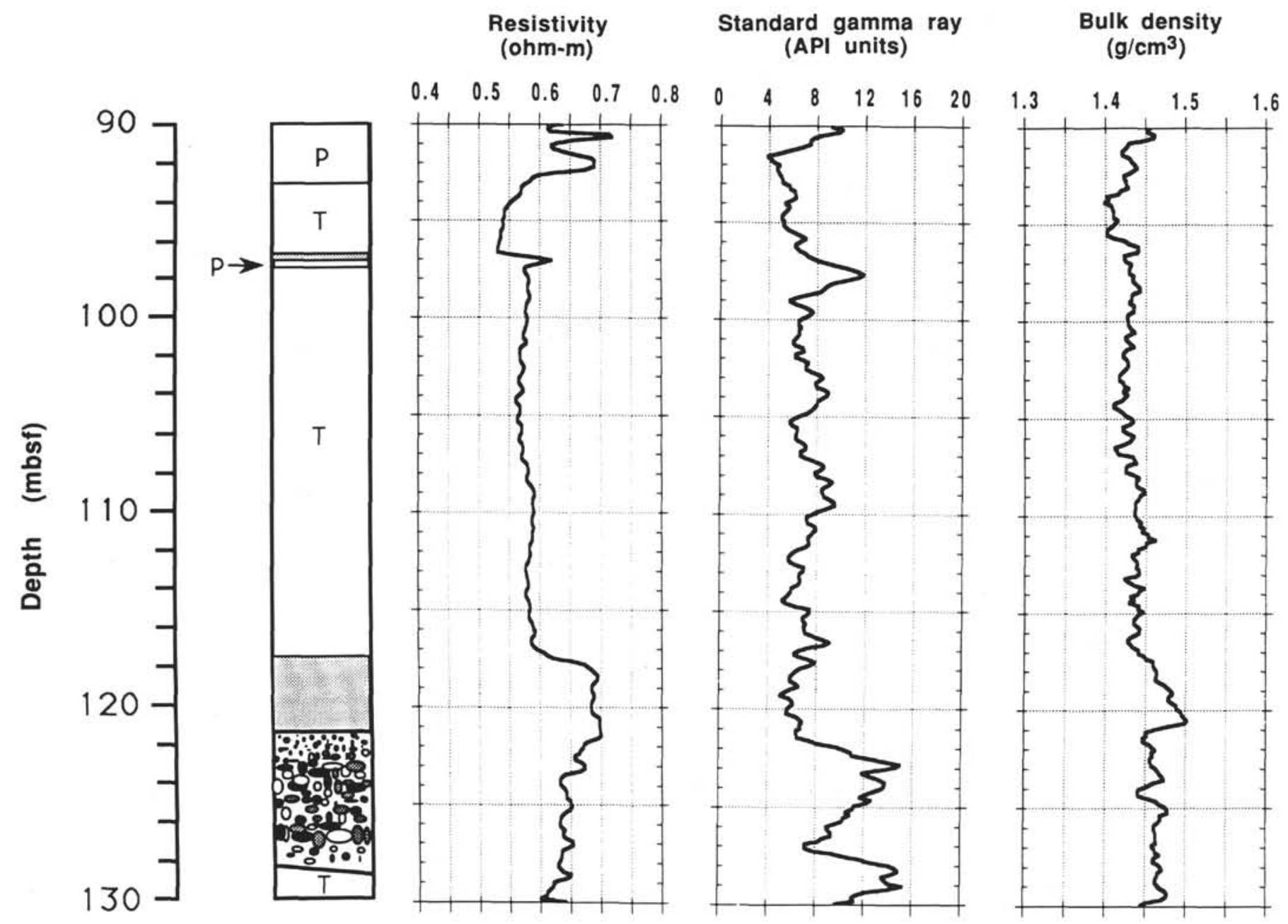

Figure 23. Downhole resistivity, standard gamma-ray, and bulk-density logs through the interval from 90 to 130 mbsf at Site 835, with lithologic log alongside. Note the broad correlation with lithology. See text for discussion. 
Site 834

Site 835

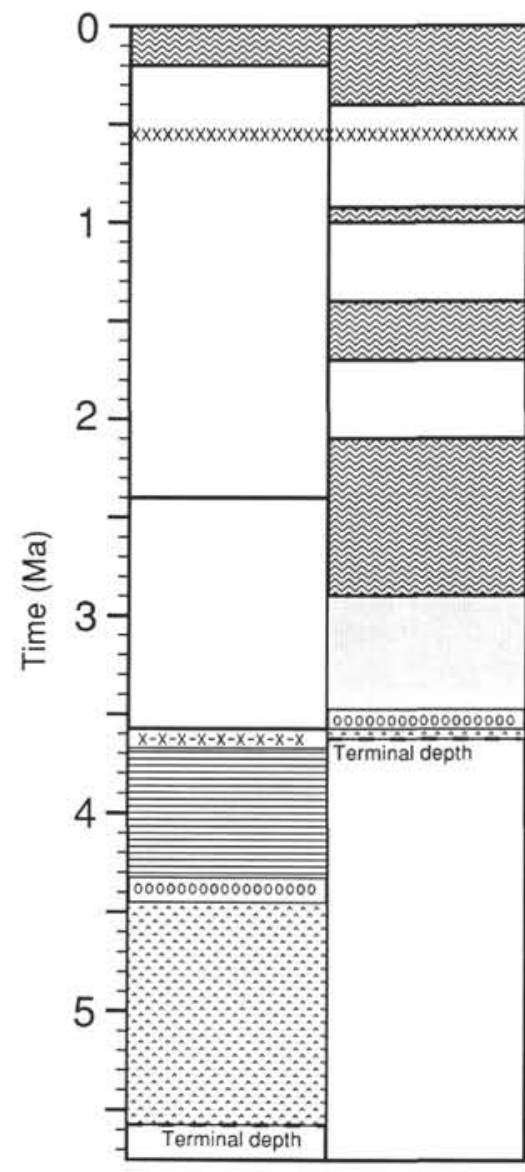

Key

Tectonically quiet

periods with

predominantly hemi-

pelagic deposition

Periods of instability

with emplacement of calcareous turbidites and at Site 835, debris flows and rafted blocks

\section{Deposition of}

common

volcaniclastic

turbidites with hemi-

pelagic interbeds

Primarily volcaniclastic

sedimentation with

deposition of thick

turbiditic volcanic sands

and silts

$\because \quad$ Eruption of basalts marking the

development of the

sub-basin

xxxx Time of closest approach of the Central Lau propagator

$x-x-x \quad$ Time of closest approach of the East Lau propagator

00000

Cessation of extrusive volcanism associated with basin formation

Figure 24. Summary diagram showing the geologic history of Sites 834 and 835 , particularly the episodes of instability at Site 835 and likely tectonic control of sedimentation. 